\title{
Driving mechanisms of organic carbon burial in the Early Cretaceous South Atlantic Cape Basin (DSDP Site 361)
}

\author{
Wolf Dummann $^{1, \mathrm{a}}$, Sebastian Steinig ${ }^{2, \mathrm{~b}}$, Peter Hofmann ${ }^{1}$, Matthias Lenz ${ }^{1}$, Stephanie Kusch ${ }^{1}$, Sascha Flögel $^{2}$, \\ Jens Olaf Herrle $^{3}$, Christian Hallmann ${ }^{4,5}$, Janet Rethemeyer ${ }^{1}$, Haino Uwe Kasper ${ }^{1}$, and Thomas Wagner ${ }^{6}$ \\ ${ }^{1}$ Institute of Geology and Mineralogy, University of Cologne, 50674 Cologne, Germany \\ ${ }^{2}$ GEOMAR Helmholtz Centre for Ocean Research Kiel, 24148 Kiel, Germany \\ ${ }^{3}$ Institute of Geosciences, Goethe University Frankfurt, 60438 Frankfurt am Main, Germany \\ ${ }^{4}$ Max Planck Institute for Biogeochemistry, 07745 Jena, Germany \\ ${ }^{5}$ MARUM, University of Bremen, 28359 Bremen, Germany \\ ${ }^{6}$ Lyell Centre, School of Energy, Geoscience, Infrastructure and Society, Heriot-Watt University, Edinburgh, EH14 4AS, UK \\ a now at: Institute of Geosciences, Goethe University Frankfurt, 60438 Frankfurt am Main, Germany \\ ${ }^{b}$ now at: School of Geographical Sciences, University of Bristol, Bristol, BS8 1SS, UK
}

Correspondence: Wolf Dummann (wdummann@uni-koeln.de)

Received: 7 February 2020 - Discussion started: 4 March 2020

Revised: 21 November 2020 - Accepted: 4 January 2021 - Published: 19 February 2021

\begin{abstract}
Extensive black shale deposits formed in the Early Cretaceous South Atlantic, supporting the notion that this emerging ocean basin was a globally important site of organic carbon burial. The magnitude of organic carbon burial in marine basins is known to be controlled by various tectonic, oceanographic, hydrological, and climatic processes acting on different temporal and spatial scales, the nature and relative importance of which are poorly understood for the young South Atlantic. Here we present new bulk and molecular geochemical data from an Aptian-Albian sediment record recovered from the deep Cape Basin at Deep Sea Drilling Project (DSDP) Site 361, which we combine with general circulation model results to identify driving mechanisms of organic carbon burial. A multimillion-year decrease (i.e., Early Aptian-Albian) in organic carbon burial, reflected in a lithological succession of black shale, gray shale, and red beds, was caused by increasing bottom water oxygenation due to abating hydrographic restriction via South Atlantic-Southern Ocean gateways. These results emphasize basin evolution and ocean gateway development as a decisive primary control on enhanced organic carbon preservation in the Cape Basin at geological timescales (> 1 Myr). The Early Aptian black shale sequence comprises alternations of shales with high $(>6 \%)$ and relatively low $(\sim 3.5 \%)$ organic carbon content of marine sources, the former being
\end{abstract}

deposited during the global Oceanic Anoxic Event (OAE) $1 \mathrm{a}$, as well as during repetitive intervals before and after OAE 1a. In all cases, these short-term intervals of enhanced organic carbon burial coincided with strong influxes of sediments derived from the proximal African continent, indicating closely coupled climate-land-ocean interactions. Supported by our model results, we show that fluctuations in weathering-derived nutrient input from the southern African continent, linked to changes in orbitally driven humidity and aridity, were the underlying drivers of repetitive episodes of enhanced organic carbon burial in the deep Cape Basin. These results suggest that deep marine environments of emerging ocean basins responded sensitively and directly to short-term fluctuations in riverine nutrient fluxes. We explain this relationship using the lack of wide and mature continental shelf seas that could have acted as a barrier or filter for nutrient transfer from the continent into the deep ocean.

\section{Introduction}

The Early Cretaceous epoch ( 145-100.5 Ma) has long been a focus of interest for geologists and the petroleum industry due to the widespread occurrence of marine black shales (i.e., organic-carbon-rich, fine-grained sediments), 
which were preferentially deposited in emerging ocean basins that developed in the wake of the breakup of Pangaea (Stein et al., 1986; Zimmerman et al., 1987). Within these basins, organic carbon (OC) burial was controlled by a complex interplay of productivity, preservation, and dilution (Pedersen and Calvert, 1990; Tyson, 2005; Arthur and Sageman, 1994; Bralower and Thierstein, 1984), which was affected by multiple processes acting on different timescales. On a multimillion-year (geological) timescale, OC burial was controlled by tectonic processes modifying basin geometry, marine gateway evolution, and ocean circulation (Donnadieu et al., 2016; Dummann et al., 2020; Arthur and Natland, 1979; Wagner and Pletsch, 1999), while shorter term (e.g., orbitally driven) changes in oceanic and atmospheric circulation triggered pronounced fluctuations in the magnitude of OC burial on timescales of tens of thousands to hundreds of thousands of years (Beckmann et al., 2005; Behrooz et al., 2018; Hofmann and Wagner, 2011; Wagner et al., 2013; Kolonic et al., 2005; Herrle et al., 2003). During brief episodes $\leq 1 \mathrm{Myr}$, marine black shales were deposited regionally to globally and accompanied by intense perturbations in ocean chemistry and ecology (Jenkyns, 2010; Weissert et al., 1998; Erba, 1994). These carbon-climate perturbation events are described as oceanic anoxic events (OAEs; Schlanger and Jenkyns, 1976). OAE 1a, one of the most severe OAEs (Jenkyns, 2010, and references therein), occurred during the Early Aptian (Coccioni et al., 1992) and was marked by a distinct negative stable carbon isotope excursion at its onset (Menegatti et al., 1998), evidence for rapid warming (O'Brien et al., 2017, and references therein) and elevated atmospheric $\mathrm{CO}_{2}$ concentrations (Naafs et al., 2016).

During the Early Aptian, at the time of OAE 1a, the emerging South Atlantic Ocean consisted of two main rift basins that progressively opened from south to north (Pérez-Díaz and Eagles, 2017) and which were separated from each other by the volcanic Walvis Ridge (Fig. 1). Each of the two subbasins acted as a major depocenter for OC-rich sediments (Zimmerman et al., 1987; Arthur and Natland, 1979; Macdonald et al., 2003) with exceptionally high OC burial rates in the Early Cretaceous. Biogeochemical modeling indicates that excess OC burial in the South Atlantic basin may have accounted for around $16 \%$ of global OC burial during the Aptian in an area that covered only around $1 \%$ of the total global ocean (McAnena et al., 2013). Data from Deep Sea Drilling Project (DSDP) Site 364, located at a paleo-latitude of $25^{\circ} \mathrm{S}$ and an estimated paleo-water depth of $\sim 300-400 \mathrm{~m}$ (Zimmerman et al., 1987) in the Angola Basin (Fig. 1), suggest that enhanced OC deposition occurred north of the Walvis Ridge during the Early to early Late Aptian, sustained by the restricted basin geometry and the continuous supply of nutrients from surrounding continents (Arthur and Natland, 1979; Behrooz et al., 2018; Naafs and Pancost, 2014). In line with previous studies (e.g., Beckmann et al., 2005), a recent study by Behrooz et al. (2018) indicates that marine OC burial dynamics at Site 364 were tightly coupled to orbitally

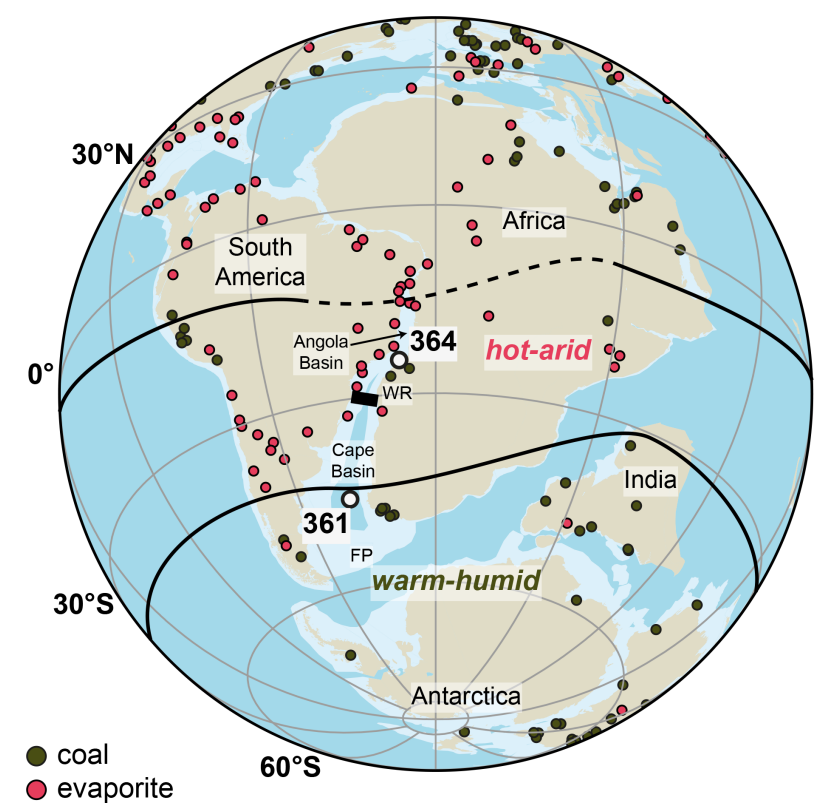

Figure 1. Aptian paleogeographic reconstruction (Matthews et al., 2016) showing the Early Cretaceous distribution of climatesensitive rock types (Boucot et al., 2013; Cao et al., 2019). Position of climate belts according to Boucot et al. (2013) and Chumakov et al. (1995). Land-sea mask and distribution of shelf seas were adapted from Cao et al. (2017). WR stands for Walvis Ridge, and FP stands for Falkland Plateau.

driven continental hydrology and run-off variability beneath the ascending, tropical limb of the atmospheric Hadley cell (the Intertropical Convergence Zone; ITCZ). Near-shore sediment records located along continental margins, such as Site 364, often show particularly pronounced cycles of variable OC quantity and quality, as this is where hydrological changes on the continent are most directly translated into marine sediments, while less pronounced cycles at sites further offshore reflect an attenuation of the signal with increasing water depth and distance from the continent (Wagner et al., 2013).

Our study investigates the driving mechanisms of marine OC burial in the deep Cape Basin (Fig. 1), south of the Walvis Ridge, and their connections to midlatitude atmospheric circulation and continental hydrology, which have been studied less extensively. We provide new inorganic and organic (bulk and molecular) geochemical data from DSDP Site 361, located at a paleo-latitude of $\sim 45^{\circ} \mathrm{S}$ and a paleowater depth of 2-2.5 km (Fig. 1; Melguen, 1978; Thiede and Van Andel, 1977; Van Andel et al., 1977), where an extensive Aptian black shale sequence was recovered (The Shipboard Scientific Party, 1978), including OAE 1a (Dummann et al., 2020). These black shales show repetitive alternations of OC-rich and (relatively) OC-poor sediments (Dummann et al., 2020), indicating highly dynamic depositional conditions on a timescale of $<1 \mathrm{Myr}$. We combine our new proxy 
data with general circulation model (GCM) data to provide insights into the nature and pacing of cyclic fluctuations in atmospheric circulation and continental hydrology at midlatitudes during the Early Cretaceous to evaluate its importance for open marine OC burial dynamics in the deep Cape Basin.

\subsection{Geological setting and stratigraphy of DSDP Site 361}

\subsubsection{Lithostratigraphy}

Site 361 was drilled on the lower continental rise of South Africa $\left(35^{\circ} 03.97^{\prime} \mathrm{S}, 15^{\circ} 26.91^{\prime} \mathrm{E}\right)$ at a modern water depth of $4549 \mathrm{~m}$ (The Shipboard Scientific Party, 1978). A total of $390 \mathrm{~m}$ of Early Cretaceous sediments were penetrated with an average core recovery of $\sim 32 \%$ (Fig. 2a). The shipboard scientific party of DSDP Leg 40 divided the Early Cretaceous sediment sequence into two lithostratigraphic units (The Shipboard Scientific Party, 1978). The lower unit (cores 28-48; Fig. 2a) is of Early Aptian age and was deposited in a deep proximal fan to fan-valley environment (Kagami, 1978; Natland, 1978). Shale intervals occur scattered throughout the Early Aptian sequence and are intercalated with sandand siltstone beds, which account for $\sim 55 \%$ of the recovered sediments (Fig. 2a). These coarse-grained beds have been interpreted as turbidites, dense traction or debris flows, and potentially bed loads (Natland, 1978). Intercalated shales are mostly fissile, partly laminated, and frequently lack bioturbation, indicating deposition under conditions of reduced bottom water oxygenation (Natland, 1978; Arthur and Natland, 1979; Thiede and Van Andel, 1977). Sedimentological evidence suggests that shales are partly of hemipelagic and turbiditic origin. The former are up to several meters thick and frequently comprise thin alternations of nannofossil layers and mudstone intervals, indicating fluctuating deposition under tranquil conditions (Natland, 1978). The latter are associated with sandstone and sandy mudstone beds and presumably represent fine-grained turbiditic material, which settled out of suspension (Kagami, 1978).

The overlying lithostratigraphic unit (cores 26-27; Fig. 2a) consists of Late Aptian gray shales and Albian red beds, in which cross-laminated siltstone beds and burrowing structures become abundant (Natland, 1978; The Shipboard Scientific Party, 1978), reflecting a strengthening of deep water circulation and ventilation, respectively (Arthur and Natland, 1979). Sandstone beds become less frequent, which has been linked to subsidence and/or erosion of sediment source regions along the Southwest African margin (Natland, 1978). This profound change in the sedimentary environment of the Cape Basin resulted from an intensified deep water mass exchange with the adjacent Southern Ocean basin (Arthur and Natland, 1979) due to the progressive opening of two gateways, namely the shallow Falkland Plateau Gateway and deep Georgia Basin Gateway (Dummann et al., 2020).
In the present study, we divide the sedimentary sequence into three lithostratigraphic units, which largely conform with the units defined by the shipboard scientific party: (1) a black shale unit present in cores 48-28 (Fig. 2a), (2) a gray shale unit in core 27, and (3) red beds in core 26. Gray shales and red beds are subdivided into two lithostratigraphic units based on their distinct color and TOC content (Fig. 2c), as proposed by Dummann et al. (2020).

\subsubsection{Biostratigraphy and carbon isotope stratigraphy}

Age constraints for Early Cretaceous sediments at Site 361 are mainly based on calcareous nannofossil biostratigraphy, originally defined by Proto Decima et al. (1978) and recently updated by Dummann et al. (2020), indicating an Early Aptian-Albian age for the investigated sediment sequence (Fig. 2a). Supported by biostratigraphy (i.e., the first occurrence of Eprolithus floralis at $\sim 1065 \mathrm{~m}$ below the sea floor, b.s.f.), Dummann et al. (2020) further identified OAE 1a in the Early Aptian black shale unit between 1089 and $1050 \mathrm{~m}$ b.s.f., based on its characteristic carbon isotope excursions (Fig. 2b; Menegatti et al., 1998).

\section{Materials and methods}

\subsection{Sampling strategy}

Sampling at Site 361 primarily targeted hemipelagic shale intervals, while turbiditic coarse-grained sediments and associated shale intervals (i.e., centimeter- to decimeter-thick shale intervals, which lie on top of and between sandstone beds) were omitted. The geochemistry of turbiditic sediments has, however, been described in previous studies (e.g., Jacquin and De Graciansky, 1988; Natland, 1978; Kagami, 1978). These studies indicate that turbidites were derived from granitic weathering source regions along the proximal southwestern African coast (Natland, 1978). TOC contents of sandstones cover a similar range to hemipelagic shales (Jacquin and De Graciansky, 1988) with a strong dominance of terrigenous OC, including preserved coal particles and wood fragments (Jacquin and De Graciansky, 1988; Raynaud and Robert, 1978). This OC was probably entrained by turbidites and transported from the shelf to the deeper basin. To ensure homogenous grain size characteristics among all investigated samples, the samples were screened using geochemical grain size proxies (i.e., $\mathrm{Si} / \mathrm{Al}$ and $\mathrm{Zr} / \mathrm{Al}$ ratios; e.g., Croudace and Rothwell, 2015, and references therein) and compared to a number of reference samples $(n=8)$ taken from turbiditic sandstones (Fig. 3a).

\subsection{Analytical methods}

\subsubsection{Major and trace element analysis by $\mathrm{XRF}$}

Major (Al, Si, K, Ti) and trace element (Zr, Ni, Cu, V, Zn) concentrations were determined on 131 shale samples and 


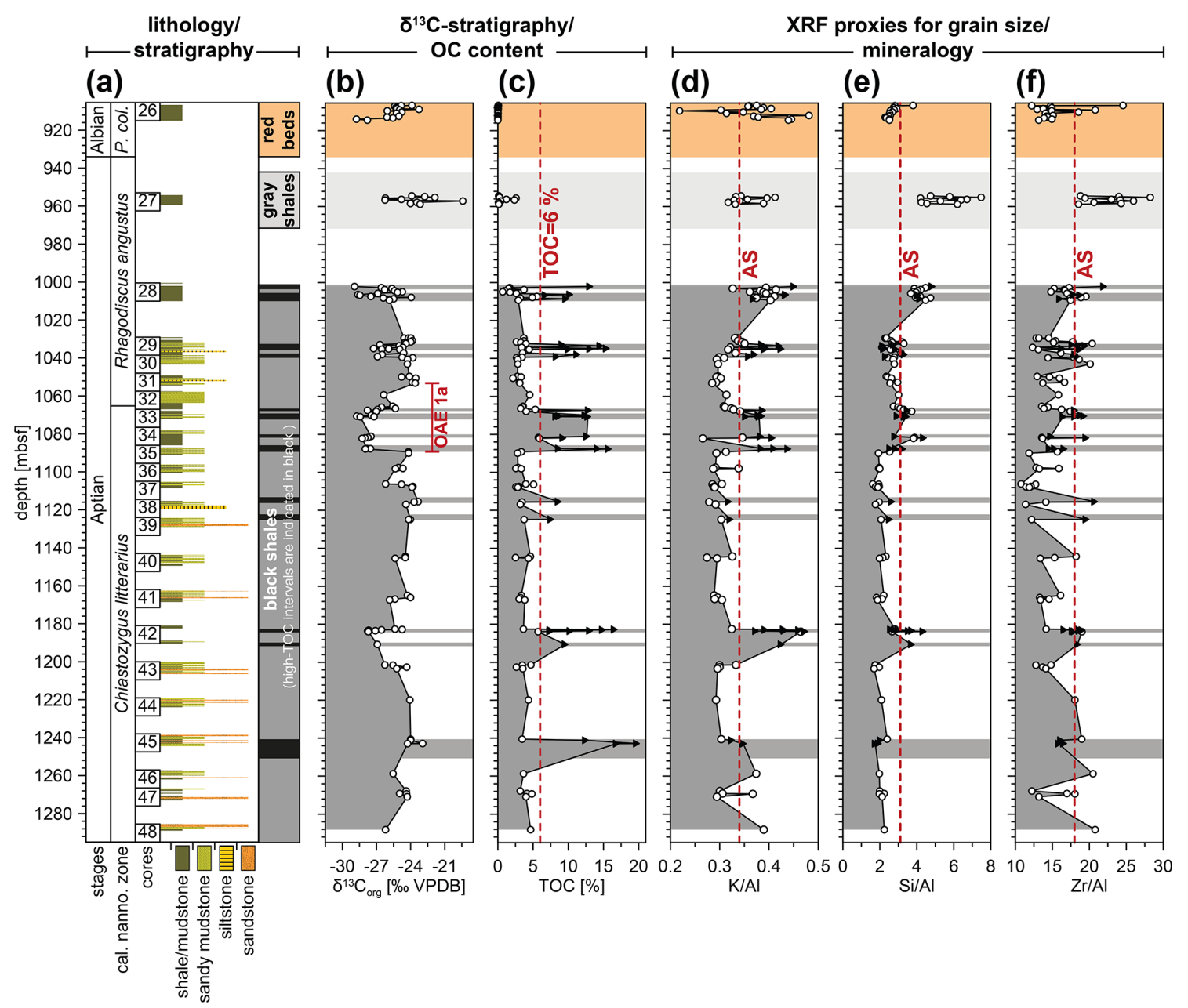

Figure 2. Stratigraphic framework and inorganic geochemistry at DSDP Site 361: (a) stage assignment, calcareous nannofossil zonation, and lithology of the studied sediment sequence; (b) bulk $\delta^{13} \mathrm{C}_{\text {org }}$; (c) total organic carbon content; (d) $\mathrm{K} / \mathrm{Al}$ ratios; (e) Si/Al ratios; and (f) $\mathrm{Zr} / \mathrm{Al}$ ratios. Black triangles with background shading indicate high-TOC black shales (>6\% TOC). Dashed lines in panels (d)-(f) represent average shale (AS) ratios. Bulk $\delta^{13} \mathrm{C}_{\text {org }}$ data and TOC content are taken from Dummann et al. (2020). P. col. is an abbreviation for Prediscosphaera columnata.

8 sandstones using an Itrax x-ray fluorescence (XRF) core scanner (Cox Analytical Systems, Sweden) equipped with a $\mathrm{Cr}$ tube. Dried and ground samples were pressed into plastic cubes, which were aligned under the core scanner. Analyses were performed at a resolution of $1 \mathrm{~mm}$ and an integration time of $60 \mathrm{~s}$ per measurement, yielding 9 to 12 individual measurements per sample, which were averaged over each sample. Absolute element concentrations were quantified by calibration against reference samples of known elemental composition, which were measured alongside the samples (for details, see Supplement file S1).

\subsubsection{Trace element analysis by ICP-MS}

In addition to XRF analysis, 15 black shale samples covering a range of TOC values from $2.5 \%-15.7 \%$ were investigated for their immobile trace element ( $\mathrm{Th}, \mathrm{Sc}, \mathrm{Zr}$ ) and rare-earth element (REE) composition. Analyses were conducted using a SCIEX ELAN 6100 inductively coupled plasma mass spectrometer (ICP-MS; Perkin Elmer, USA) following total acid digestion. Aliquots of dried and ground samples were combusted at $550^{\circ} \mathrm{C}$ for $4 \mathrm{~h}$ to remove $\mathrm{OC}$ and subsequently decomposed in a pressure digestion system (PDS6, Loftfields Analytical Solutions, Germany) following published protocols (Dulski, 2001). Acids used for digestion were HF (40\%, suprapure, Merck, Germany), $\mathrm{HNO}_{3}$ (65\%, suprapure, Merck, Germany), $\mathrm{HClO}_{4}(70 \%$, ultrapure, VWR, USA), and $\mathrm{HCl}$ (30\%, suprapure, Merck, Germany). Quantification was conducted using two external multi-element standard solutions $\left(1 \mathrm{ng}^{-1}, 10 \mathrm{ng}^{-1}\right)$ and a matrix solution. An internal $\mathrm{Ru}$ and $\mathrm{Re}$ standard was analyzed alongside the samples to monitor instrumental drift. Two certified reference materials (CRM) JA-2 (Dulski, 2001) and GA (Govin- 
(a)

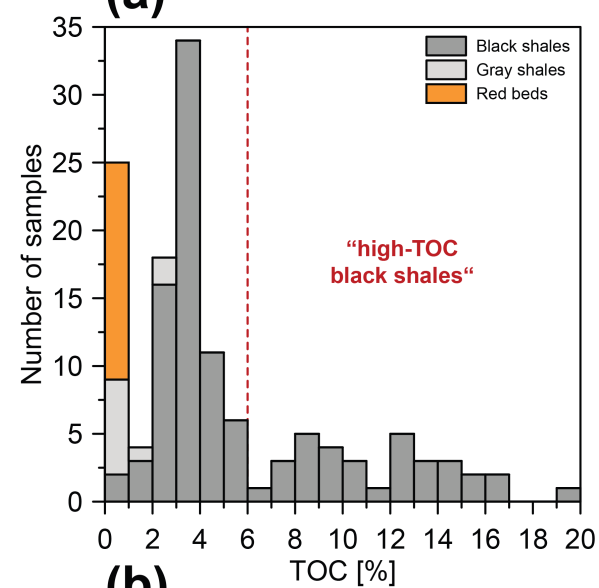

(b)
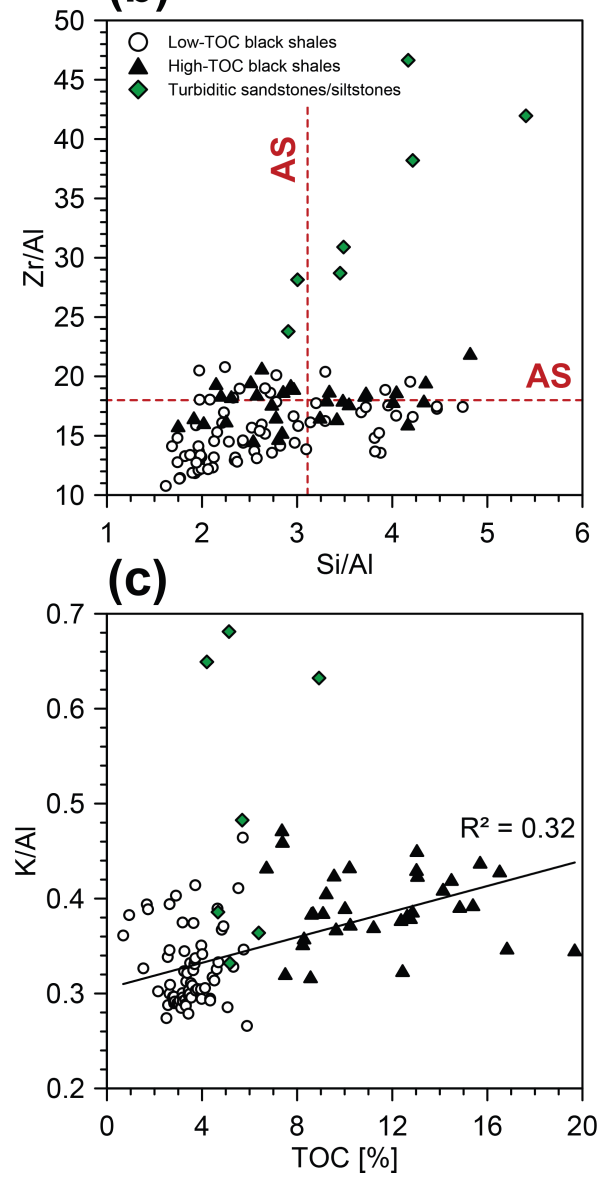

Figure 3. Geochemical characteristics of the different lithostratigraphic (sub)units: (a) histogram showing the TOC contents of samples from different lithostratigraphic units (i.e., black shales, gray shales, and red beds). Panel (b) shows cross-plots of XRF-derived grain size proxies $\mathrm{Si} / \mathrm{Al}$ and $\mathrm{Zr} / \mathrm{Al}$ for black shale samples, which are grouped into high-TOC black shales (TOC $>6 \%$ ) and lowTOC black shales (TOC $<6 \%$ ). Green diamonds represent samples taken from intercalated sandstones, which are plotted for reference. Panel (c) shows cross-plots of TOC content and $\mathrm{K} / \mathrm{Al}$ ratios. AS stands for average shale. daraju, 1994) were used to monitor precision and accuracy. All standards reproduced within $\pm 3 \%$.

\subsubsection{Lipid biomarker analysis}

Aliquots from 71 samples (1-8g) were extracted with methanol (Merck SupraSolv ${ }^{\circledR}$, Germany; $30 \mathrm{~mL}$ ), methanol and dichloromethane $(1: 1, v: v ; 30 \mathrm{~mL})$, and dichloromethane (Merck SupraSolv ${ }^{\circledR}$, Germany; $30 \mathrm{~mL}$ ) for $10 \mathrm{~min}$ each in an ultrasonic bath. The extracts were combined in a separatory funnel and mixed with ultrapure water to remove methanol. The dichloromethane fraction was decanted and dried under mild vacuum $\left(40^{\circ} \mathrm{C}, 800 \mathrm{mbar}\right)$ using a rotary evaporator. Acid-activated copper turnings were added to the extracts to remove elemental sulfur. The samples were saponified using a $0.5 \mathrm{~mol}$ potassium hydroxide solution (methanol: water 9:1, v:v). Neutral lipids were extracted from the saponification solution with hexane (Merck SupraSolv ${ }^{\circledR}$, Germany) and partitioned into three polarity fractions (aliphatic hydrocarbons, aromatic hydrocarbons, and heteroatomic nitrogen-sulfur-oxygen (NSO) compounds) over a self-packed silica column (500 mg, 0.063-0.200 mm, 70-230 mesh, Merck, Germany; deactivated with $1 \%$ ultrapure water) using hexane, hexane and dichloromethane $(2: 1, v: v)$, and dichloromethane and methanol $(1: 1, v: v)$, respectively. To reduce interferences during mass spectrometric analysis, the aliphatic fraction was further separated into saturated and unsaturated compounds using silver-ion chromatography (10\% $\mathrm{AgNO}_{3}$-coated silica gel, Sigma-Aldrich, USA), which were eluted with hexane and ethyl acetate (Merck SupraSolv ${ }^{\circledR}$, Germany), respectively. Deuterated internal standards (i.e., $d_{50}$-tetracosane and $d_{4}$-cholestane) were used for quantification and added to the saturated aliphatic fraction prior to analysis.

The saturated aliphatic fractions were analyzed using coupled gas chromatography-mass spectrometry (GC-MS) and gas chromatography-tandem mass spectrometry (GCMS/MS). The distribution of acyclic hydrocarbons (i.e., $n$ alkanes, acyclic isoprenoids) was analyzed using an Agilent 6890N GC coupled to an Agilent 5975 mass selective detector (MSD) operated in selected ion monitoring (SIM) mode scanning for $m / z 85\left(\left[\mathrm{C}_{6} \mathrm{H}_{13}\right]^{+}\right)$and $m / z 98\left(\left[\mathrm{C}_{6} \mathrm{D}_{13}\right]^{+}\right)$ fragments. Samples were injected onto a DB5-MS column $(50 \mathrm{~m}, 0.2 \mathrm{~mm}, 0.25 \mu \mathrm{m})$ using a split/splitless injector operated in splitless mode and heated from 70 to $250^{\circ} \mathrm{C}$. Helium was used as carrier gas at a constant flow rate of $1.3 \mathrm{~mL} \mathrm{~min}^{-1}$. The GC temperature was held at $40^{\circ} \mathrm{C}$ for $2 \mathrm{~min}$, increased to $140^{\circ} \mathrm{C}$ at $10^{\circ} \mathrm{C} \mathrm{min}{ }^{-1}$, and then to $320^{\circ}$ $\mathrm{C}$ at $5{ }^{\circ} \mathrm{C} \mathrm{min}^{-1}$. The final temperature was held for $22 \mathrm{~min}$. Ionization was achieved by electron impact (EI) at $70 \mathrm{eV}$ and $230^{\circ} \mathrm{C}$. Reproducibility was monitored using an authentic $n$ alkane standard solution and was better than $1 \%$.

Sterane and hopane distributions were analyzed using an Agilent 7890B GC coupled to an Agilent 7000C electron im- 
pact triple quadrupole mass spectrometer (EI-TQ-MS) operated in multiple reaction monitoring (MRM) mode. Samples were injected onto a HP5-MS column $(50 \mathrm{~m}, 0.25 \mathrm{~mm}$, $0.25 \mu \mathrm{m}$ ) using a split/splitless injector operated in splitless mode at $290^{\circ} \mathrm{C}$. Helium was used as carrier gas at a constant flow rate of $1.2 \mathrm{~mL} \mathrm{~min}^{-1}$. The initial GC temperature was held at $60^{\circ} \mathrm{C}$ for $2 \mathrm{~min}$, then increased to $140^{\circ} \mathrm{C}$ at $10^{\circ} \mathrm{C} \mathrm{min}^{-1}$ and to $320^{\circ} \mathrm{C}$ at $4{ }^{\circ} \mathrm{C} \mathrm{min}^{-1}$, which was held for $15 \mathrm{~min}$. Ionization was achieved by $\mathrm{EI}$ at $70 \mathrm{eV}$ and $300^{\circ} \mathrm{C}$. Argon was used as a collision gas at a collision energy of $10 \mathrm{~V}$. Reproducibility was monitored using an in-house standard containing all targeted compounds at similar concentration levels. The reproducibility of measurements varied between different compounds and was mostly better than $5 \%$ but always better than $10 \%$ for all reported biomarker ratios.

\subsection{General circulation modeling}

Model simulations were carried out with the Kiel Climate Model (KCM; Park et al., 2009). The KCM uses the ECHAM5 spectral atmospheric model with a horizontal resolution of $\sim 2.8^{\circ}$ (T42) on 19 vertical levels (Roeckner et al., 2003) coupled to the ocean-sea ice component NEMO (Madec, 2008) on a tripolar grid with a horizontal resolution of $2^{\circ}$ (ORCA2) and 31 vertical levels. The meridional ocean resolution gradually increases to $0.5^{\circ}$ towards the Equator. Modifications to the model for the Early Cretaceous configuration are described in Dummann et al. (2020). We slightly modified the bathymetry of the area north of the Walvis Ridge $\left(\sim 30^{\circ} \mathrm{S}\right)$ by replacing the Early Albian paleobathymetry used in Dummann et al. (2020) with the Early Aptian boundary conditions of Sewall et al. (2007) to account for the reduced northward extent of the Angola Basin during the Aptian (Fig. S1 in Supplement file S4).

Two 3000-year-long simulations with atmospheric $p \mathrm{CO}_{2}$ levels of 600 and $1200 \mathrm{ppm}$ were performed to reflect published range of stomata-based $p \mathrm{CO}_{2}$ reconstructions for the Aptian-Albian (Jing and Bainian, 2018) and enhanced $p \mathrm{CO}_{2}$ levels during OAE 1a (Naafs et al., 2016), respectively. Even though peak $p \mathrm{CO}_{2}$ concentrations during the hyperthermal phase of OAE 1a may have been even higher (Naafs et al., 2016), Steinig et al. (2020) showed that the KCM is capable of simulating upper ocean temperatures at a $p \mathrm{CO}_{2}$ of $1200 \mathrm{ppm}$, which are broadly consistent with the lower end of proxy reconstructions for OAE 1a. This model-data congruence can be achieved by assuming a regional warm bias in the Early Cretaceous TEX $_{86}$ record in the young Atlantic Ocean. We are therefore confident that our $1200 \mathrm{ppm}$ $p \mathrm{CO}_{2}$ model represents an OAE 1a-like climate state reasonably well, while the $600 \mathrm{ppm}$ simulation instead reflects lower Early Cretaceous background $p \mathrm{CO}_{2}$ levels (Jing and Bainian, 2018). Results were averaged over the last 100 model years, when the model reached a quasi-steady state with a globally depth-integrated temperature drift over 1000 model years of below $0.2^{\circ} \mathrm{C}$ (Fig. S2 in Supplement file S4).
We further performed orbital sensitivity experiments at 600 and $1200 \mathrm{ppm} p \mathrm{CO}_{2}$ to assess the influence of cyclic fluctuations in solar insolation on continental hydrology. $\mathrm{Nu}-$ merical solutions for orbital parameters beyond $\sim 50$ Ma become highly uncertain (Laskar et al., 2011). We therefore followed the method of Crowley et al. (1993) and defined two end-member configurations representing maxima and minima in summer insolation, implementing Pleistocene ranges for eccentricity, obliquity, and precession (Berger, 1978). Both simulations with low and high $p \mathrm{CO}_{2}$ concentrations used a constant eccentricity of 0.06 with varying obliquity and precession to create a "warm summer orbit" $\left(24.5^{\circ}\right.$ obliquity; perihelion during southern summer solstice) and a "cold summer orbit" (22.0 $0^{\circ}$ obliquity; perihelion during southern winter solstice) for the Southern Hemisphere. The sensitivity experiments were branched off from a modern orbit simulation (eccentricity $=0.0167$; obliquity $=23.44$; longitude of perihelion $=283$ ) after 2500 model years and integrated for another 500 years to allow the atmospheric dynamics to adapt to the orbital perturbation.

\section{Results}

\subsection{Total organic carbon content}

TOC contents and bulk $\delta^{13} \mathrm{C}_{\text {org }}$ data at Site 361 were previously reported by Dummann et al. (2020). Aptian-Albian sediments at Site 361 range from $0 \%$ to $19.7 \%$ TOC (Figs. 2c and 3a) with marked differences between the three lithostratigraphic units (i.e., black shales, gray, and red beds). Red beds and gray shales generally contain $<0.1 \%$ TOC and $0.1 \%-2.6 \%$ TOC, respectively, while TOC contents of black shales range from $0.7 \%$ to $19.7 \%$ (Fig. 3a). Black shale samples with $<3 \%$ TOC are generally confined to short intervals in core 28 in the top part of black shale unit (Fig. 2c). We broadly subdivide the black shale unit into "low-TOC black shales" (i.e., 0.7\%-6\% TOC) and "high-TOC black shales" (i.e., $>6 \% \mathrm{TOC}$ ) to differentiate two OC burial end-member states and to facilitate the discussion of related changes in paleo-environmental conditions. The former subunit comprises the majority of black shale samples (i.e., $70 \%$ ), which cluster around a mean of $3.5 \%$ TOC (Fig. 3a) and appear to constitute background sedimentation during the Early Aptian (Fig. 2c). High-TOC black shales contain a broad range of TOC contents (i.e., $6 \%-19.7 \%$; Fig. 3a) and, by contrast, are restricted to narrow (several decimeters to meters thick) and repetitive stratigraphic intervals (Fig. 2c). We note, however, that changes in TOC content across individual highTOC intervals often occur gradually and are unrelated to visible changes in sedimentary facies. These observations suggest that both subunits are interrelated and may represent a continuum. As such, the exact placement of the TOC threshold is to some extent arbitrary. 


\subsection{Sediment composition and provenance}

\subsubsection{Distribution of $\mathrm{K}, \mathrm{Si}$, and $\mathrm{Zr}$}

To track changes in geochemical composition related to grain size and mineralogy of the sediments, we report $\mathrm{K} / \mathrm{Al}, \mathrm{Si} / \mathrm{Al}$, and $\mathrm{Zr} / \mathrm{Al}$ ratios obtained by XRF analysis (Fig. 2d-f). All black shales at Site 361 show $\mathrm{Si} / \mathrm{Al}$ and $\mathrm{Zr} / \mathrm{Al}$ ratios typical for fine-grained sediments with ratios close to average shale (AS) values (Wedepohl, 2004, 1971) and are distinctly lower than in intercalated turbiditic sandstones (Figs. 2e, $\mathrm{f}$ and $3 \mathrm{~b}$ ). Neither $\mathrm{Si} / \mathrm{Al}$ nor $\mathrm{Zr} / \mathrm{Al}$ ratios differ substantially between high-TOC and low-TOC black shale intervals. In contrast, $\mathrm{K} / \mathrm{Al}$ ratios vary in concert with TOC (Figs. 2d and 3c), with high-TOC black shales showing a higher mean $\mathrm{K} / \mathrm{Al}$ ratio of $0.39 \pm 0.04(\bar{x} \pm 1 \sigma)$ compared to low-TOC black shales with a mean ratio of $0.32 \pm 0.05$. Turbiditic sandstones show $\mathrm{K} / \mathrm{Al}$ ratios, which mostly cover the same range as shale samples. Some sandstones, however, show substantially higher $\mathrm{K} / \mathrm{Al}$ ratios of $>0.6$ (Fig. 3c).

\subsubsection{Sediment provenance}

Immobile trace element and REE geochemistry were used to constrain the provenance of Early Aptian black shales. To define provenance types and tectonic settings, we used discrimination plots following the approach of Bhatia and Crook (1986) and McLennan et al. (1993), respectively. Furthermore, potential sediment source regions located on the proximal southern African continent were identified based on comparison with geochemical data compiled from the literature. This data compilation comprising shale and mudstone samples from sediment source regions is provided in Supplement files S2 and S3 and includes all relevant references.

All black shale samples show trace element and REE patterns typical for continental crust with clear differences between low-TOC and high-TOC black shales (Fig. 4ce). Low-TOC black shales show characteristics typical for a recycled sedimentary rock provenance (McLennan et al., 1993), including $\mathrm{Th} / \mathrm{Sc}>1$ and enrichment of $\mathrm{Zr} / \mathrm{Sc}$ relative to Th/Sc (Fig. 4c). In addition, all low-TOC samples show $\mathrm{Th} / \mathrm{Zr}$ and $\mathrm{La} / \mathrm{Sc}$ ratios indicative for an active continental margin signature (Fig. 4d), implying a felsic to intermediate sediment source composition, which is also supported by a strong enrichment of the light REE La, Ce, Pr, Nd, and Sm and a pronounced negative Eu anomaly (Fig. 4e). All above proxy parameters overlap with those reported from the Karoo and Cape supergroup (Fig. 4c-e).

In contrast, the trace element and REE signature of highTOC black shales suggests a greater contribution from mafic sediment sources, as indicated by slightly lower Th/Sc ratios (Fig. 4c), lower La/Sc ratios (Fig. 4d), and depletion of light REE compared to low-TOC black shales (Fig. 4e). HighTOC samples plot close to the continental island arc endmember (Fig. 4d), indicating a bulk sediment source composition close to granodiorite. Potential source regions com- prising mafic rocks include the Kaapvaal Craton and Karoo volcanics (Fig. 4c-e).

\subsection{Inorganic paleo-redox parameters}

\subsubsection{Distribution of sulfur and iron}

The stratigraphic variation of sulfur content closely parallels that of the TOC content (Fig. 5b). Sulfur contents of Early Aptian black shales fluctuate around a mean value of $2.9 \% \pm 1.4 \%$ and decrease to $0.4 \% \pm 0.5 \%$ in Late Aptian gray shales. Albian red beds are essentially sulfur-free. LowTOC black shales are characterized by a mean sulfur content of $2.2 \% \pm 0.5 \%$, while high-TOC black shales contain approximately twice as high sulfur contents $(4.5 \% \pm 1.6 \%)$.

$\mathrm{Fe}, \mathrm{S}$, and TOC relationships are used to differentiate between paleo-redox states based on diagnostic $\mathrm{S} / \mathrm{C}$ and $\mathrm{S} / \mathrm{Fe}$ ratios (Fig. 6; Dean and Arthur, 1989; Arthur and Sageman, 1994); the latter of which approximate the degree of pyritization (DOP; Raiswell et al., 1988). Red bed and gray shale samples scatter around a $\mathrm{S} / \mathrm{C}$ mixing line of $\sim 0.4$, typical for sediments deposited in an oxic environment (Berner and Raiswell, 1983; Leventhal, 1983). Gray shales and red beds show $\mathrm{S} / \mathrm{Fe}$ ratios well below the threshold value of 0.45 , which is generally used to discriminate oxic from "restricted" (i.e., suboxic-anoxic) conditions (Raiswell et al., 1988). Black shales show overall higher $\mathrm{S} / \mathrm{Fe}$ ratios, covering a broader range between the 0.25 and the pyrite line. Low-TOC black shales and high-TOC black shales cluster into two populations with minor overlap. $\mathrm{S} / \mathrm{Fe}$ ratios of low-TOC black shales fall close to 0.45 , with a relatively large scatter between 0.25 and 0.75 . High-TOC black shales instead tend to have $\mathrm{S} / \mathrm{Fe}$ ratios greater than 0.45 , often exceeding 0.75 (mean of $0.85 \pm 0.24$ ), indicating "inhospitable" (i.e., strictly anoxic to euxinic) conditions (Raiswell et al., 1988).

\subsubsection{Distribution of redox-sensitive trace metals}

Distributions of the redox-sensitive trace metals (TMs) Ni, $\mathrm{Cu}, \mathrm{V}$, and $\mathrm{Zn}$ in black shales are presented as TM/Al ratios in Fig. 5c-f and enrichment factors (EFs) relative to AS values in Fig. 7. All TM/Al ratios co-vary closely with each other and with TOC (Fig. 5c-f). Albian red beds all show TM/Al close to or below AS values with mean EFs of $0.7 \pm 0.2,0.9 \pm 0.7,0.8 \pm 0.5$, and $0.1 \pm 0.2$ for $\mathrm{Ni}, \mathrm{Cu}, \mathrm{V}$, and Zn, respectively. Similarly low EFs for V $(1.3 \pm 0.4)$ and Zn (1.8 \pm 1.4$)$ are present in Late Aptian gray shales, which, however, show substantially higher EFs for Ni $(3.4 \pm 1.4)$ and $\mathrm{Cu}(3.2 \pm 1.0)$. Low-TOC black shales show minor, if any, TM enrichment beyond AS values, with mean EFs of $1.2 \pm 1.3,1.3 \pm 0.8,2.0 \pm 2.0$, and $3.2 \pm 5.4$ for $\mathrm{Ni}, \mathrm{Cu}, \mathrm{V}$, and $\mathrm{Zn}$, respectively. In contrast, high-TOC black shales are characterized by consistently higher TM EFs, with V and $\mathrm{Zn}$ being particularly enriched, as indicated by mean EFs of $10.5 \pm 5.9$ and 31.4 \pm 32.6 , respectively. Enrichment of $\mathrm{Ni}$ 


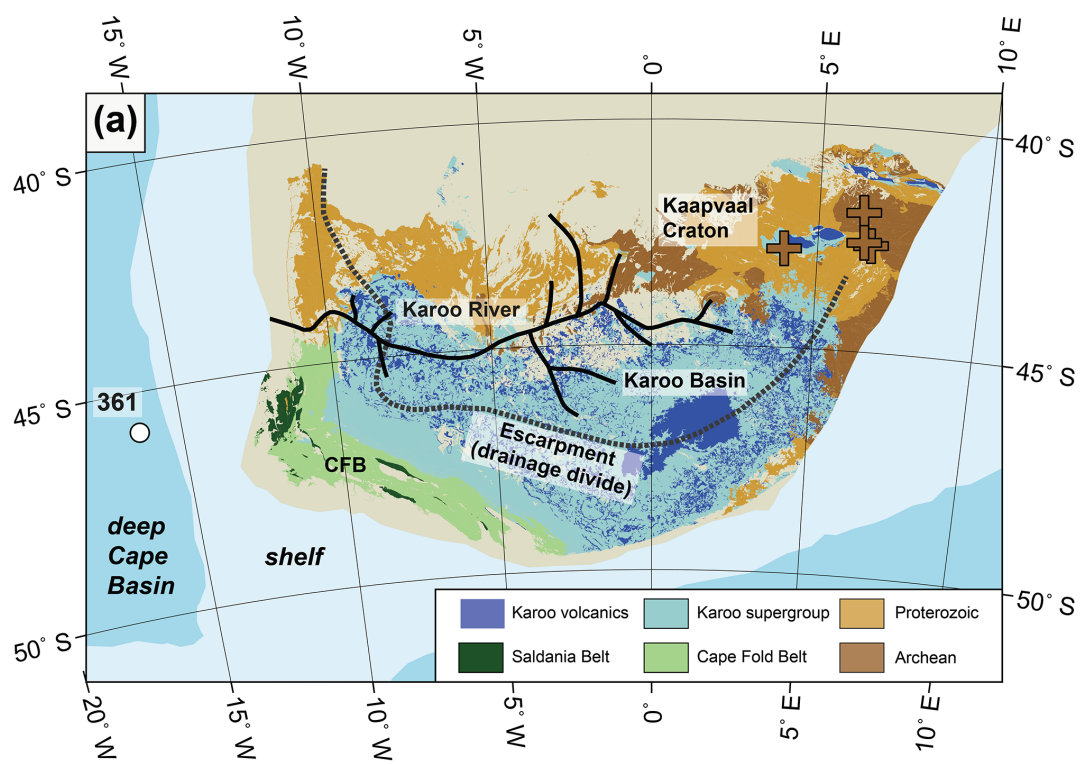

(b)

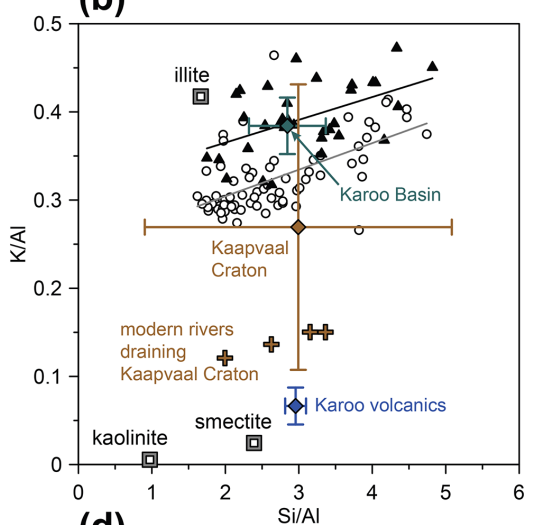

(c)
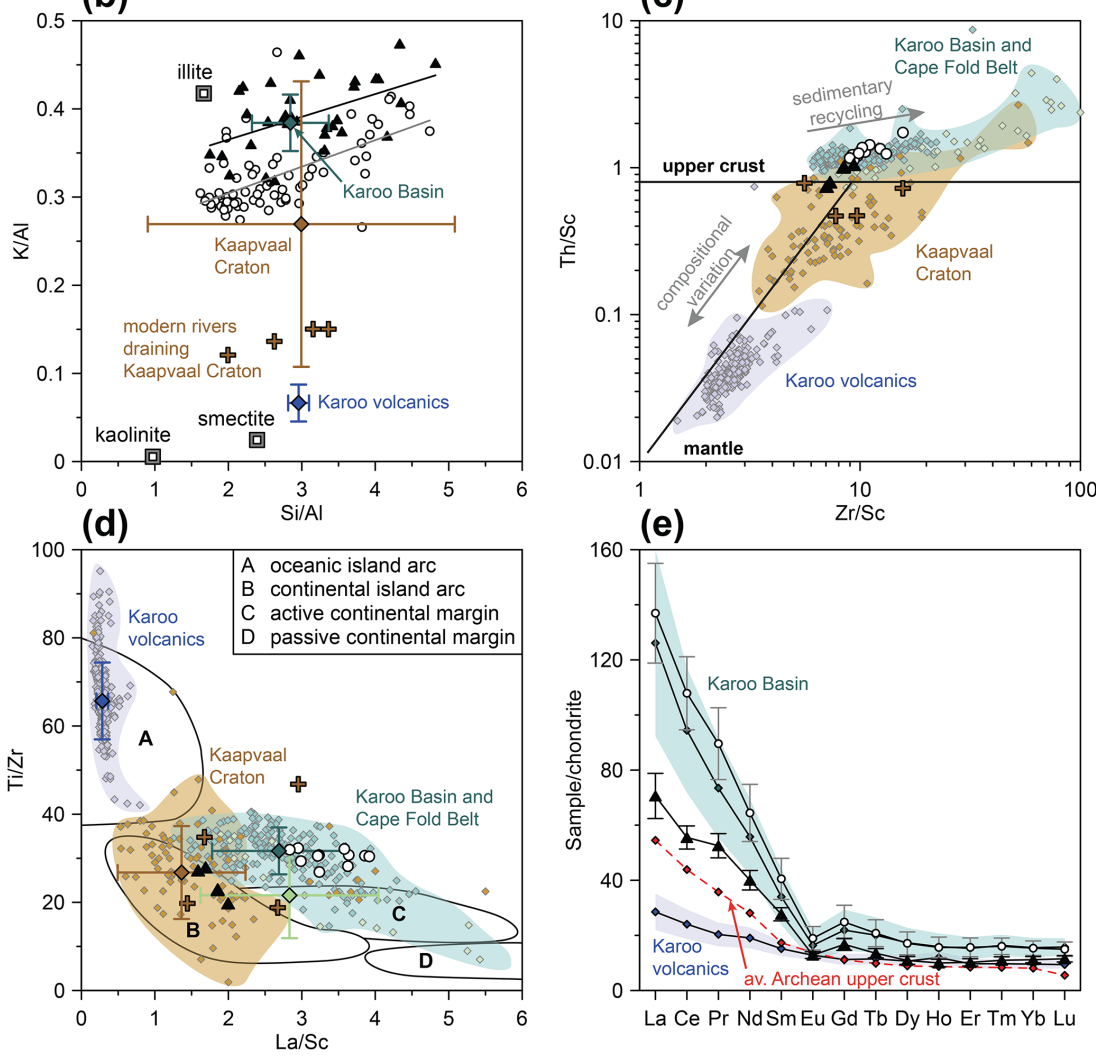

\begin{tabular}{|llll|}
\hline & \multicolumn{1}{|c|}{ Key } & \\
$\Delta 361$ high-TOC black shales & $\diamond$ Cape supergroup & $\diamond$ Kaapvaal craton \\
0361 low-TOC black shales & $\diamond$ Cape supergoup median $( \pm \sigma)$ & $\diamond$ Kaapvaal craton median $( \pm \sigma)$ \\
$\diamond$ Karoo supergroup & $\diamond$ Karoo volcanics & \pm modern rivers draining Kaapvaal craton \\
$\diamond$ Karoo supergroup median $( \pm \sigma)$ & $\diamond$ Karoo volcanics median $( \pm \sigma)$ & \\
\hline
\end{tabular}

Figure 4. Provenance assessment of Early Aptian black shales based on major and trace metal discrimination plots: (a) geological map of southern Africa showing potential sediment source areas. Early Cretaceous paleo-drainage reconstruction adapted from De Wit (1999). Panel (b) shows cross-plots of Si/Al and K/Al. Average elemental composition of different clay minerals was taken from Weaver and Pollard (1973). Panels (c) and (d) show cross-plots of Zr/Sc vs. Th/Sc (McLennan et al., 1993) and La/Sc vs. Ti/Zr (Bhatia and Crook, 1986), respectively. Panel (e) shows chondrite-normalized rare-earth element distributions. Trace element data for source areas were compiled from the literature. Data and references are provided in Supplements files S2 and S3. 

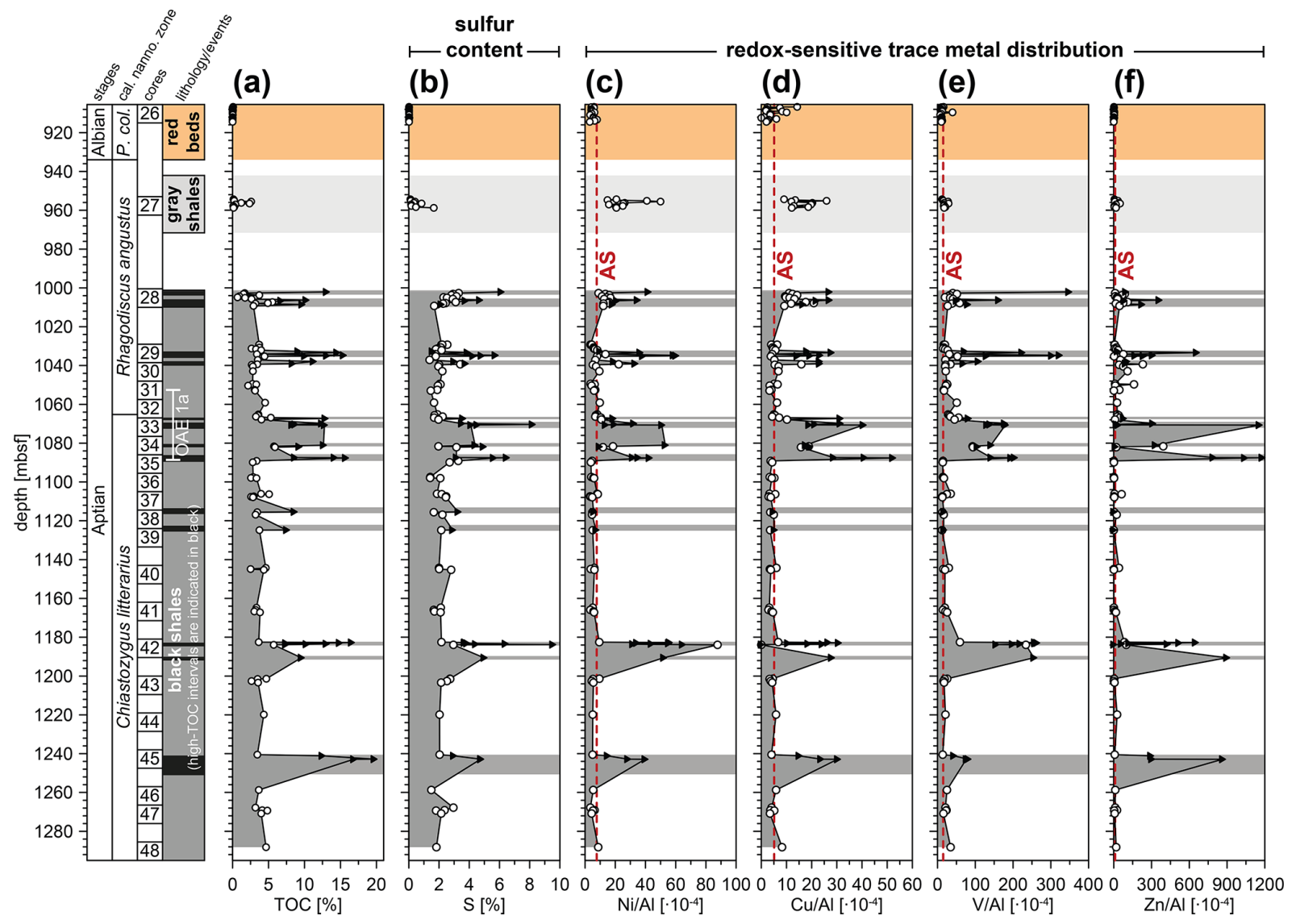

Figure 5. Inorganic geochemical parameters used to reconstruct paleo-redox conditions: (a) total organic carbon content (Dummann et al., 2020); (b) total sulfur content; and (c-f) Ni/Al, Cu/Al, V/Al, and Zn/Al ratios. Black triangles with background shading indicate high-TOC black shales (>6\% TOC). Average shale TM/Al ratios (AS) are plotted as red dashed lines. $P$. col. is short for Prediscosphaera columnata.

and $\mathrm{Cu}$ in high-TOC black shales is more modest with mean values of $4.4 \pm 2.2$ and $4.5 \pm 2.0$, respectively.

Cross-plots of TM EFs against TOC provide additional information on the mechanisms of sedimentary TM enrichment and thus paleo-redox conditions (Tribovillard et al., 2006; Algeo and Maynard, 2004). High-TOC black shales show pronounced differences in TM-TOC relationships for $\mathrm{Ni}, \mathrm{Cu}$, $\mathrm{V}$, and $\mathrm{Zn}$ relative to low-TOC black shales (Fig. 7). Ni and $\mathrm{Cu}$ EFs tend to increase with TOC content, although only $\mathrm{Cu}$ exhibits a clear linear relationship $\left(R^{2}=0.38\right)$ to TOC content. In contrast, $\mathrm{V}$ and $\mathrm{Zn}$ EFs show a substantial scatter and no relationship to TOC content.

\subsection{Biomarker distribution}

Our biomarker assessment focuses on thermal maturity, OC sources, and paleo-redox conditions, for which we report selected biomarker parameters, while a detailed discussion of a whole suite of biomarkers is beyond the scope of this study.

\subsubsection{Thermal maturity}

Sediments at Site 361 are thermally immature at an estimated $\mathrm{R}_{O}$ of $<0.4 \%$ (Peters et al., 2007). Steranes mainly possess the thermally least stable $5 \alpha, 14 \alpha, 17 \alpha(\mathrm{H})-20 \mathrm{R}$ or $5 \beta, 14 \alpha, 17 \alpha(\mathrm{H})-20 \mathrm{R}$ stereoisomeric configurations. Thermally unstable $17 \beta, 21 \beta(\mathrm{H})$-hopanes dominate over more stable $17 \alpha, 21 \beta(\mathrm{H})$ and $17 \beta, 21 \alpha(\mathrm{H})$ hopanes and the most stable configurations such as $17 \alpha, 21 \beta(\mathrm{H})-30 \mathrm{~S}$ homohopanes and $18 \alpha(\mathrm{H})-22,29,30$-trisnorneohopane (Ts) are either absent or occur in trace amounts only. The ratios of $17 \beta, 21 \beta(\mathrm{H}) /[17 \alpha, 21 \beta(\mathrm{H})+17 \beta, 21 \alpha(\mathrm{H})+17 \beta, 21 \beta(\mathrm{H})]-$ $\mathrm{C}_{30}$-hopane ( $\beta \beta$-hopane-ratios) vary between 0.08 and 0.36 (mean of $0.18 \pm 0.06$; Fig. 8 b), do not increase downcore, and show no systematic trend when compared to TOC, indicating that thermal maturation effects had a negligible impact on down-core variations in the biomarker distribution.

\subsubsection{Organic carbon sources}

Variations in OC sources are assessed based on the relative abundances of $n$-alkanes, desmethylsteranes, and regu- 


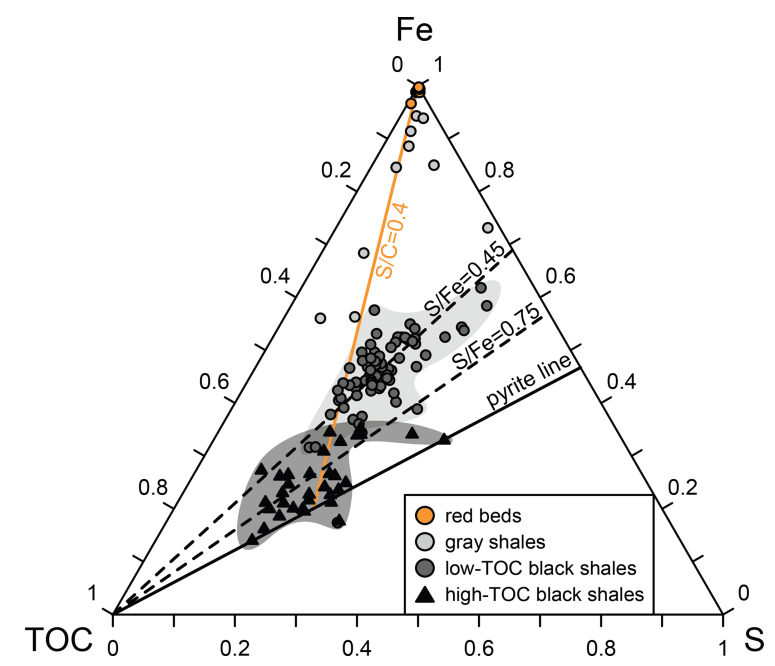

Figure 6. Ternary diagram illustrating TOC, S, and Fe relationships in the different lithostratigraphic (sub)units. Characteristic $\mathrm{S} / \mathrm{Fe}$ and $\mathrm{S} / \mathrm{C}$ ratios used to discriminate redox states (i.e., oxic conditions: $\mathrm{S} / \mathrm{C}=0.4$ and $\mathrm{S} / \mathrm{Fe}<0.45$; suboxic-anoxic conditions: $\mathrm{S} / \mathrm{Fe}=0.45-0.75$; and strictly anoxic-euxinic conditions: $\mathrm{S} / \mathrm{Fe}>0.75$ ) are plotted as proposed by Raiswell et al. (1988), Leventhal (1983), and Berner and Raiswell (1983). TOC data are taken from Dummann et al. (2020).

lar hopanes (i.e., $\mathrm{C}_{27}$ and $\mathrm{C}_{29}-\mathrm{C}_{33}$ hopanes). Chain lengths of $n$-alkanes range from $\mathrm{C}_{15}$ to $\mathrm{C}_{35}$. High molecular weight (HMW) $\mathrm{C}_{25}$ to $\mathrm{C}_{35} n$-alkanes show an odd-over-even predominance (with a mean carbon preference index $\mathrm{CPI}_{25-33}$ of 1.9; Bray and Evans, 1961), indicating a higher land plant origin (Bray and Evans, 1961; Eglinton and Hamilton, 1967). The ratio of low molecular weight (LMW) $\mathrm{C}_{15}, \mathrm{C}_{17}$, and $\mathrm{C}_{19} n$-alkanes, indicative of algal and/or bacterial OC input (Han and Calvin, 1969), to HMW odd carbon-numbered $\mathrm{C}_{25}$ to $\mathrm{C}_{35} n$-alkanes varies from 0.2 to 6.7 (Fig. $8 \mathrm{c}$ ). LowTOC black shales show a lower mean LMW/HMW ratio of $1.3 \pm 1.1$ compared to high-TOC black shales, which have a mean LMW/HMW ratios of $2.1 \pm 1.4$.

A suite of $\mathrm{C}_{27}$ to $\mathrm{C}_{35}$ hopanes, reflecting OC inputs from prokaryotic or bacterial sources, and regular $\mathrm{C}_{27}$ to $\mathrm{C}_{30}$ desmethylsteranes, indicative of eukaryotic OC sources, are present in varying concentrations. Eukaryotic OC generally dominates over bacterial $\mathrm{OC}$, as indicated by sterane / hopane ratios (ratio of $\mathrm{C}_{27}$ to $\mathrm{C}_{29}$ desmethylsteranes to regular $\mathrm{C}_{27}$ and $\mathrm{C}_{29}$ to $\mathrm{C}_{33}$ hopanes) ranging from 2.3 to 62.5 (Fig. 8d). Low-TOC black shales are characterized by mean sterane / hopane ratios of $10.9 \pm 9.3$, which increase in highTOC black shale interval to a mean value of $28.3 \pm 12.8$.

The extended 24- $n$-propylcholestane (24-npc), a proxy that can indicate contributions of marine algae to OC (Moldowan et al., 1990), is present throughout the record. We normalize the abundance of 24-npc to $\mathrm{C}_{29}$-desmethylsterane, which is generally linked to higher land plant inputs (Huang and Meinschein, 1979), to approximate the relative contri- bution of marine and terrigenous OC. The ratios of 24npc / $\mathrm{C}_{29}$-sterane co-vary with TOC (Fig. 8e) and range between 0.06 and 0.35 . Low-TOC black shales show a 24npc / $\mathrm{C}_{29}$-sterane mean ratio of $0.14 \pm 0.08$, which increases to $0.21 \pm 0.09$ in high-TOC black shales.

Fractional abundances of regular $\mathrm{C}_{27}, \mathrm{C}_{28}$, and $\mathrm{C}_{29}$ steranes, depicted as a ternary diagram (Fig. 9), are used to differentiate different eukaryotic sources (Huang and Meinschein, 1979). Higher land plant-derived $\mathrm{C}_{29}$-steranes tend to dominate in low-TOC black shales, while $\mathrm{C}_{27}$ and $\mathrm{C}_{28}$ dominate over $\mathrm{C}_{29}$ in high-TOC black shales, suggesting a greater contribution of marine OC.

\subsubsection{Paleo-redox conditions}

Our molecular paleo-redox assessment is based on the distribution of lycopane, a tail-to-tail linked acyclic isoprenoid, the occurrence of which is limited to anoxic depositional settings (Sinninghe Damsté et al., 2003). Lycopane abundances are normalized to $\mathrm{C}_{31} n$-alkane, following Sinninghe Damsté et al. (2003). Lycopane $/ n-\mathrm{C}_{31}$ ratios range from 0.04 to 4.8 and co-vary closely with TOC (Fig. 8f), with low-TOC black shales and high-TOC black shales showing mean ratios of $0.7 \pm 0.5$ and $1.7 \pm 1.0$, respectively. Furthermore, we screened the aromatic hydrocarbon fraction of all samples for isorenieratene derivatives and related compounds, whose presence imply photic-zone euxinia (Koopmans et al., 1996). However, no isorenieratene derivatives were detected in any of the analyzed samples.

\section{Discussion}

\subsection{Temporal trends in organic carbon burial}

Changes in OC burial in the Aptian-Albian Cape Basin occurred on different timescales. On a multimillion-year timescale, OC burial decreased in two steps, as reflected in the lithological succession of black shales in the Aptian $(6.0 \pm 4.4 \%$ TOC), gray shales in the latest Aptian $(0.8 \pm 1.0 \%$ TOC $)$, and red beds in the Albian $(<0.1 \%$ TOC). Superimposed on this long-term trend, we identify several distinct episodes of enhanced OC burial (i.e., highTOC black shales), punctuating the Early Aptian interval (Fig. 2c). Most of these high-TOC intervals reach peak TOC levels well above $10 \%(11.5 \pm 3.2 \%$ TOC), clearly separating them from background sedimentation with still elevated but much lower TOC content $(3.5 \pm 1.0 \%$ TOC). These high-TOC intervals occurred during different time intervals across the Aptian, including, but not limited to, OAE 1a (Fig. 2b, c). The exact duration and the frequency of these intervals is difficult to assess based on the incomplete stratigraphic coverage at Site 361; i.e., they may have lasted longer, and there may have been other high-TOC intervals in non-recovered sediment sections. However, comparable TOC alternations in black shale sequences have been 
(a)

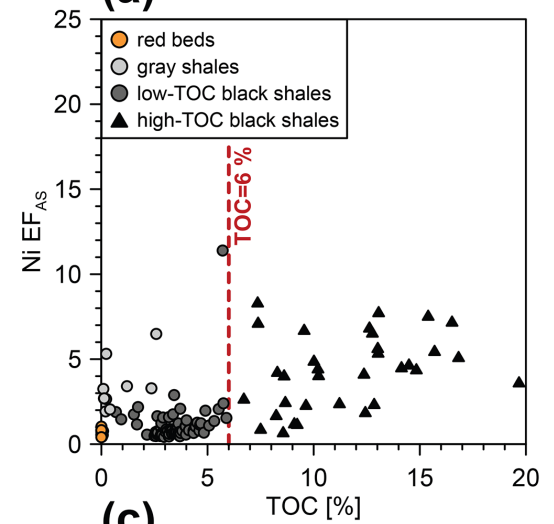

(c)

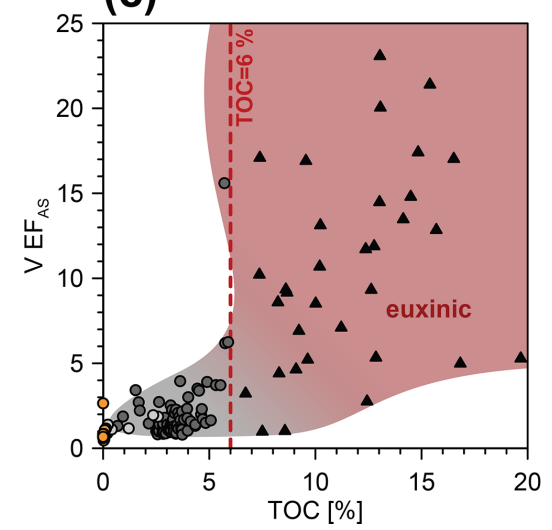

(b)

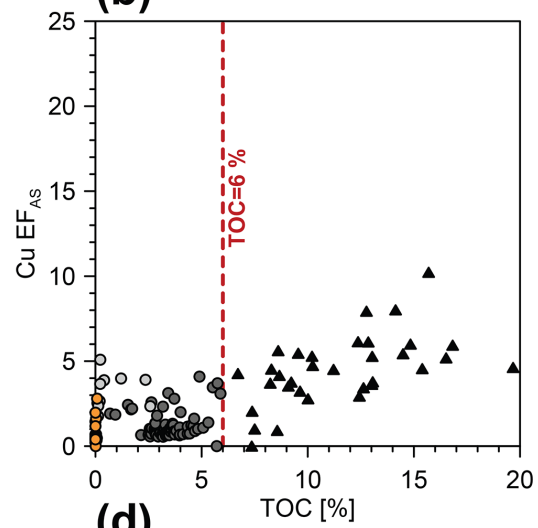

(d)

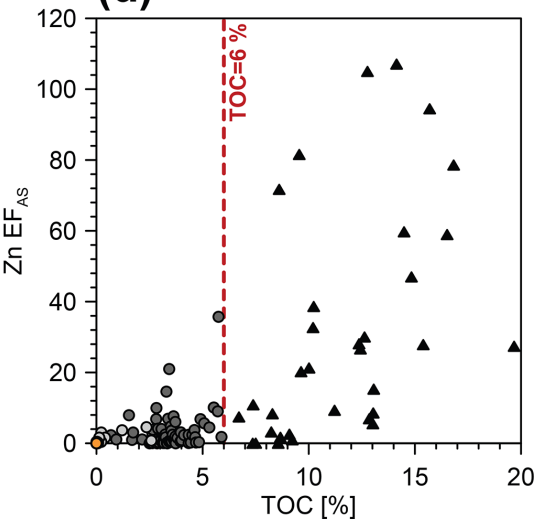

Figure 7. Cross-plots of total organic carbon content and average shale-normalized enrichment factors $\left(\mathrm{EF}_{\mathrm{AS}}\right) \mathrm{of}(\mathbf{a}) \mathrm{Ni}$, (b) $\mathrm{Cu}$, (c) $\mathrm{V}$, and (d) Zn. Black triangles indicate high-TOC black shales (>6\% TOC). TOC data are taken from Dummann et al. (2020).

reported from both the North Atlantic and South Atlantic basins throughout the Cretaceous and have been attributed to geochemical expressions of large-scale climate variations driven by orbital forcing (Beckmann et al., 2005; Behrooz et al., 2018; Hofmann and Wagner, 2011; Wagner et al., 2013; Kolonic et al., 2005; Herrle et al., 2003). To test the impact of orbital forcing on OC burial, we conducted a series of GCM experiments implementing different orbital configurations (i.e., variations in precession and obliquity). The setup of our GCM is geared to simulate atmospheric processes, including changes in precipitation, run-off, and wind-driven oceanic upwelling, all of which are known to directly or indirectly influence the magnitude of marine OC burial (e.g., Wagner et al., 2013, and references therein). Based on our proxy and GCM results, we provide a depositional model for these episodes of enhanced OC burial, which is discussed in the context of large-scale reorganizations of tectonic and oceanographic boundary conditions induced by the opening of South Atlantic-Southern Ocean gateways (Dummann et al., 2020).

\subsection{Paleo-redox variations}

\subsubsection{Paleo-redox conditions during black shale deposition in the Early Aptian}

Early Aptian black shales contain high $\mathrm{S}$ contents of $2.9 \pm 1.4 \%$ (Fig. 5b) with $\mathrm{S} / \mathrm{Fe}$ ratios $0.6 \pm 0.3$ (Fig. 6) and high abundances of the redox-sensitive biomarker lycopane, as reflected in elevated lycopane $/ n-\mathrm{C}_{31}$ ratios of $1.1 \pm 0.9$ (Fig. 8f), which fall within the range of modern anoxic settings, e.g., oxygen minimum zones along the Peru Margin and the northern Arabian Sea (Sinninghe Damsté et al., 2003). These observations indicate low oxygen concentrations in porewaters and bottom waters during the Early Aptian. $\mathrm{S} / \mathrm{Fe}$ ratios of $\sim 0.5$ (indicating a DOP range of $0.45-0.75$, Raiswell et al., 1988) and a limited degree of authigenic TM enrichment (TM EFs close to AS values) in low-TOC black shales suggest overall dysoxic-suboxic conditions during background sedimentation. Consistent with paleo-bathymetric reconstructions (Pérez-Díaz and Eagles, 2017) and sedimentological evidence (Arthur and Natland, 1979), we link reduced oxygen conditions to sluggish deep water ventilation, caused by the narrow and restricted geometry of the Early Aptian Cape Basin. In support of this hypothesis, our GCM results indicate nearly stagnant deep wa- 

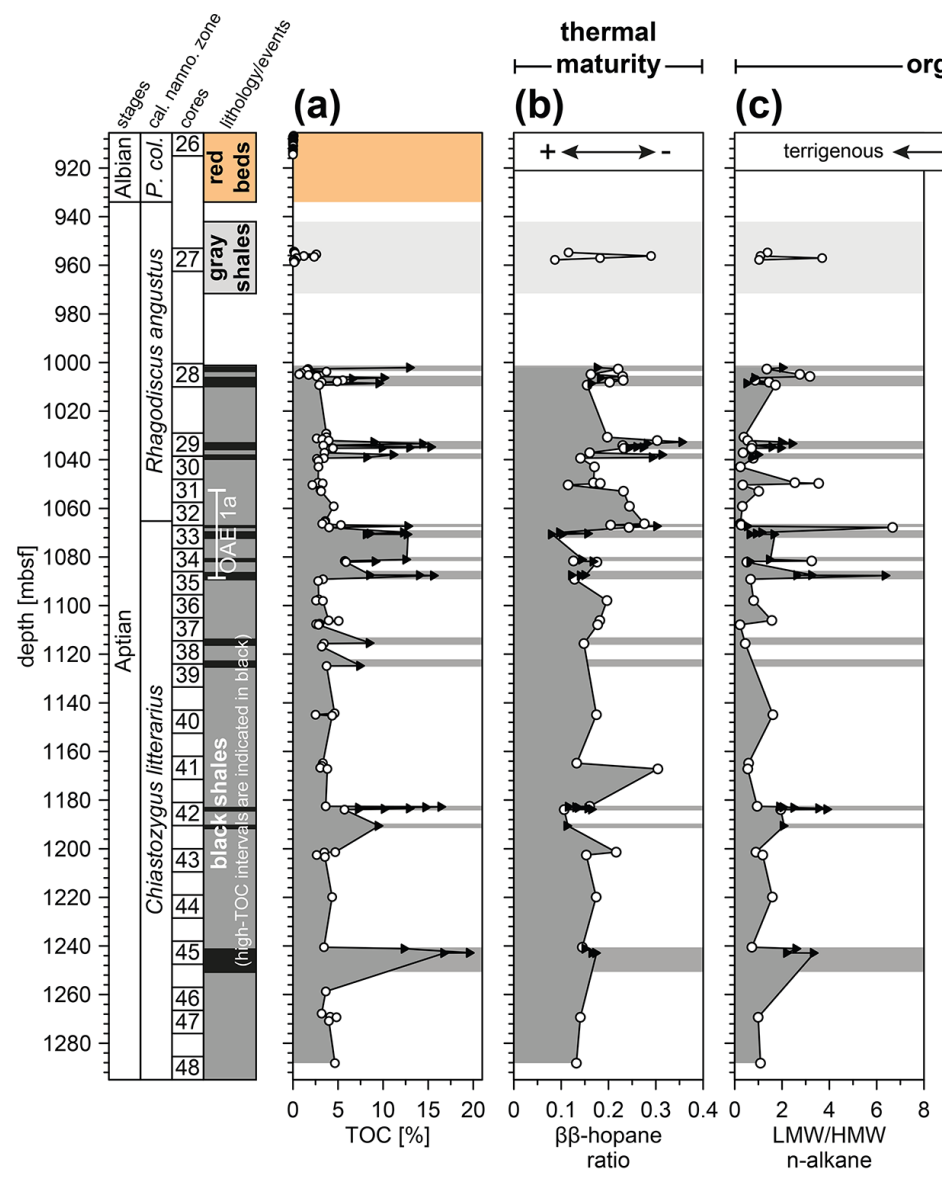

rganic carbon source

(e)
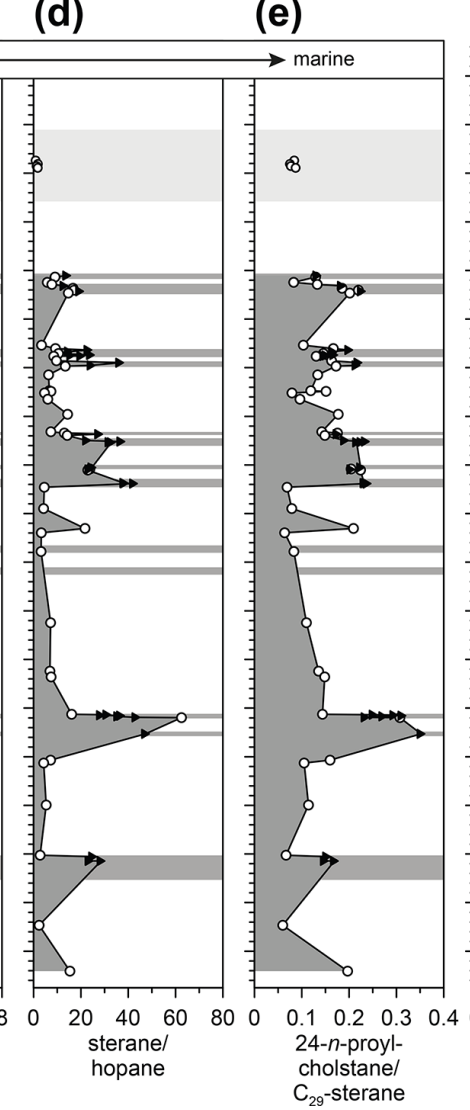

redox $\vdash$ conditions -1

(f)

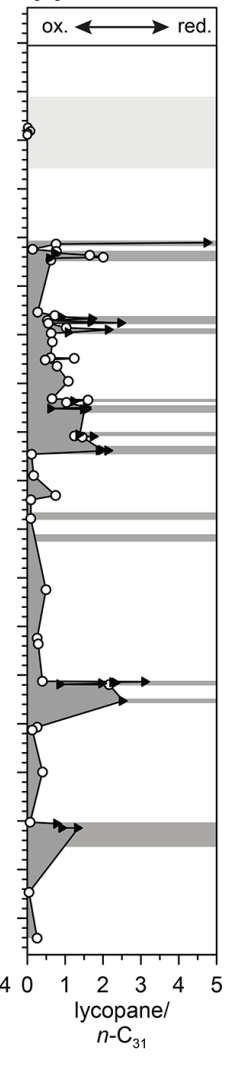

Figure 8. Distribution of selected biomarker parameters used to reconstruct thermal maturity, OC source, and paleo-redox conditions: (a) total organic carbon content (Dummann et al., 2020), (b) $\beta \beta /(\beta \beta+\alpha \beta+\beta \alpha)$ - $\mathrm{C}_{30}$-hopane ratio, (c) low molecular weight/high molecular weight $n$-alkane ratio, (d) sterane / hopane ratio, (e) 24- $n$-propylcholestane $/ \mathrm{C}_{29}$-sterane ratio, and (f) lycopane / $n$ - $\mathrm{C}_{31}$ ratio. Black triangles with background shading indicate high-TOC black shales (>6\% TOC). P. col. is short for Prediscosphaera columnata.

ter circulation in the deepest parts of the Cape Basin, where warm and saline waters accumulated (Fig. S3 in Supplement file S4). This halokinetic mode of deep water circulation is generated in all model runs, regardless of implemented climatic boundary conditions (i.e., $p \mathrm{CO}_{2}$ levels of 600 and 1200 ppm; Fig. S3 in Supplement file S4), indicating that it represents a persistent feature of South Atlantic overturning circulation during the Early Aptian.

Anoxia intensified during high TOC intervals, as indicated by (1) a doubling of sulfur contents (Fig. 5b), (2) sharp increases in redox-sensitive $\mathrm{TM} / \mathrm{Al}$ ratios (Fig. 5c-f), and (3) elevated lycopane $/ n-\mathrm{C}_{31}$ ratios (Fig. $8 \mathrm{f}$ ). Furthermore, $\mathrm{Fe}, \mathrm{S}$, and TOC relationships show that most of high-TOC black shales have $\mathrm{S} / \mathrm{Fe}$ ratios greater than 0.75 (Fig. 6), arguing for strictly anoxic-euxinic conditions (Raiswell et al., 1988). Distinguishing euxinic conditions, characterized by accumulation of $\mathrm{H}_{2} \mathrm{~S}$ in the water column, from non-sulfidic but anoxic ("ferruginous") conditions is difficult based on $\mathrm{Fe}, \mathrm{S}$, and TOC systematics alone. The distribution of redox- sensitive TMs, however, may serve to distinguish these subtle fluctuations at the extreme end of the redox scale (Algeo and Maynard, 2004; Tribovillard et al., 2006; Meyer and Kump, 2008).

At Site 361, all analyzed redox-sensitive TMs show close parallel trends of enrichment and depletion concurrent with TOC variations (Fig. 5). This strong similarity of trends between different redox-sensitive TMs supports that changes in the dissolved TM inventory are negligible and that paleoredox conditions exerted the dominant control over TM enrichment (Algeo and Maynard, 2008). Cross-plots of TM EFs and TOC reveal two distinct patterns of TM enrichment for $\mathrm{Ni}$ and $\mathrm{Cu}$ and $\mathrm{V}$ and $\mathrm{Zn}$ in high-TOC black shales (Fig. 7). $\mathrm{Ni}$ and $\mathrm{Cu}$ EFs increase in parallel with TOC content, suggesting that excess TM enrichment was controlled by OC supply to the sediment. Such a coupling of $\mathrm{Ni}$ and $\mathrm{Cu}$ enrichment with OC flux has been observed in sediments deposited under both anoxic ferruginous conditions and euxinic conditions (Algeo and Maynard, 2004; Tribovillard et 


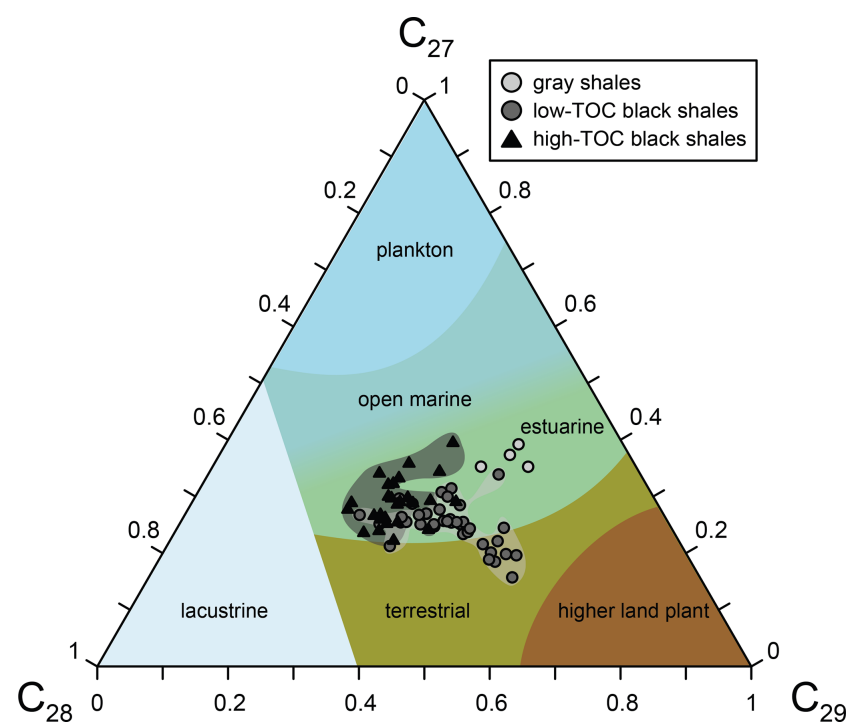

Figure 9. Ternary diagram showing the distribution of regular desmethylsteranes in gray shales, low-TOC black shales $(<6 \%$ TOC), and high-TOC black shales (>6\% TOC). Organic carbon source end-members were adapted from Huang and Meinschein (1979).

al., 2006) and mainly stems from their behavior as micronutrients (Tribovillard et al., 2006; Little et al., 2015). In contrast, high-TOC black shales are characterized by substantial enrichment of $\mathrm{V}$, which is decoupled from OC input, as indicated by the lack of correlation between V EFs and TOC (Fig. 7c). This mode of $\mathrm{V}$ enrichment supports euxinic conditions at the sediment-water interface and possibly the (lower) water column (Algeo and Maynard, 2004; Tribovillard et al., 2006). The presence of free $\mathrm{H}_{2} \mathrm{~S}$ favors reduction to V(III) (Wanty and Goldhaber, 1992), which forms insoluble hydroxide phases that can precipitate in quantity from the water column and/or the sediment-water interface, leading to a decoupling of V supply from OC flux. Zn EFs exhibit a distribution similar to V EFs (Fig. 7d), which is typical for euxinic settings and potentially results from the formation of independent zinc sulfide ( $\mathrm{ZnS}$ ) phases at the sediment-water interface (Algeo and Maynard, 2004). Further evidence for euxinic conditions during high-TOC intervals comes from the occurrence of type IIS kerogens (Hartwig et al., 2012), indicating excess availability of sulfur.

In contrast to many Mesozoic black shales deposited under euxinic conditions (Meyer and Kump, 2008, and references therein), high-TOC black shales at Site 361, however, do not contain biomarkers derived from phototrophic $\mathrm{H}_{2} \mathrm{~S}$ oxidizing bacteria (i.e., isorenieratene derivatives and other aryl isoprenoids; Koopmans et al., 1996). This general lack of photic-zone euxinia-indicating compounds at Site 361 puts constraints on the extent of water column euxinia and suggests that $\mathrm{H}_{2} \mathrm{~S}$ did not pervade into the upper water column. The oceanographic conditions that favored this limited extent of euxinia are difficult to assess based on the data presented here. However, our GCM results indicate relatively vigorous overturning at intermediate water depths in the Cape Basin (i.e., < 1000 m; Fig. S3 in Supplement file S4). These water masses, which have previously been identified and referred to as "South Atlantic intermediate waters" by Dummann et al. (2020), may have caused an efficient ventilation at intermediate water depths, thereby providing a barrier for upward migration of $\mathrm{H}_{2} \mathrm{~S}$ into shallow waters.

\subsubsection{Early Aptian-Albian long-term increase in seawater oxygenation}

Early Aptian black shales were replaced by Late Aptian gray shales and Albian red beds (Fig. 2c), reflecting a decrease in OC burial over at least $13 \mathrm{Myr}$ (Gradstein et al., 2012). Our multi-proxy paleo-redox data suggest that this long-term decline in OC burial was accompanied by major redox changes in the deep Cape Basin. Evidence includes (1) a stepwise decrease in sulfur concentrations (Fig. 5b), (2) shifts in Fe, S, and TOC relationships with decreasing $\mathrm{S} / \mathrm{Fe}$ ratios (Fig. 6), (3) a decrease in redox-sensitive trace element enrichment, in particular of V and Zn (Fig. 5c-f), and (4) decreasing lycopane / $n-\mathrm{C}_{31}$ ratios (Fig. 8f; Sinninghe Damsté et al., 2003). These results are consistent and suggest a two-step shift from suboxic-anoxic/euxinic to suboxic and oxic conditions, respectively, which was caused by a strengthening of deep water ventilation due the progressive opening of two South Atlantic-Southern Ocean gateways located on the Falkland Plateau and in the Georgia Basin, as indicated by a recent study based on Nd-isotope data and ocean current simulations (Dummann et al., 2020).

It is noteworthy, however, that Late Aptian gray shales show relatively high EFs of $\mathrm{Ni}$ and $\mathrm{Cu}$ but not the other TMs (Fig. 5c-f). Taking above lines of evidence into account, we consider it unlikely that this enrichment stems from redoxrelated authigenic processes, but it instead suggests additional processes supplying micro-nutrients to Late Aptian sediments in the Cape Basin through detrital input (Garver et al., 1996) or scavenging by biogenic silica (Böning et al., 2015; Twining et al., 2012). The exact mechanism, however, remains to be identified.

\subsection{Composition of organic carbon in Early Aptian black shales}

Both low TOC and high-TOC black shales contain thermally immature $\mathrm{OC}$, as indicated by the continuous down-core presence of $5 \beta$-steranes and $17 \beta, 21 \beta$-hopanes. $\beta \beta$-Hopane ratios do not increase downcore and show no systematic trend with TOC (Fig. 8b). Hence, changes in the sterane and hopane biomarker distribution due to thermal maturation are negligible and are interpreted to reflect primary variations in the source and/or preservation of OC. 
Early Aptian low-TOC background sediments contain a mixture of marine and terrestrial $\mathrm{OC}$ with a greater proportion of terrestrial OC compared to high-TOC black shale intervals, as indicated by (1) lower LMW/HMW $n$-alkane ratios (Fig. 8c), (2) lower sterane/hopane ratios (Fig. 8d) indicating a higher contribution from bacteria, typical for land-derived OC (e.g., Moldowan et al., 1985), (3) lower 24-npc / $\mathrm{C}_{29}$-sterane ratios (Fig. 8e), and (4) higher abundances of $\mathrm{C}_{29}$-sterane (Fig. 9). These results are consistent with previously published Rock-Eval data that show a dominance of terrigenous type III kerogen in low-TOC black shales (Hartwig et al., 2012).

In contrast, high-TOC black shales mainly comprise marine $\mathrm{OC}$, as indicated by the dominance of LMW $n$-alkanes (Fig. 8c). In connection with high sterane/hopane ratios (Fig. 8d), the dominance of algal $\mathrm{C}_{27}$-sterane and $\mathrm{C}_{28}$ sterane over higher land plant-derived $\mathrm{C}_{29}$-sterane support a predominantly marine OC source (Fig. 9; Huang and Meinschein, 1979; Moldowan et al., 1985). Increased 24$\mathrm{npc} / \mathrm{C}_{29}$-sterane ratios similarly suggest enhanced input of marine OC (Fig. 8e), as 24-npc has been linked to OC inputs from chrysophyte algae (Moldowan et al., 1990) and/or Rhizaria (Nettersheim et al., 2019), a group of heterotrophic unicellular protists, including Foraminifera and Radiolaria that occurs ubiquitously in the global ocean and plays a key in the export of carbon from the photic zone to sediments (Caron, 2016; Lampitt et al., 2009). Based on the above lines of evidence, we conclude that high-TOC black shales mark episodes of enhanced productivity and preservation of marine OC in the Cape Basin. This is further supported by the occurrence of II and IIS kerogens with hydrogen index values of up to $700 \mathrm{mg} \mathrm{g}^{-1}$ TOC in high-TOC black shales (Herbin et al., 1987; Hartwig et al., 2012).

\subsection{Depositional processes and provenance of Early Aptian black shales}

Early Aptian black shales are intercalated with abundant sandstones, sandy mudstones, and siltstones (Fig. 2a), which represent turbidites deposited in a fan to fan-valley environment (The Shipboard Scientific Party, 1978; Natland, 1978). This raises the question as to whether high TOC-low TOC alternations reflect changes between turbiditic and hemipelagic sedimentation, similar to those observed at numerous sites in the opening North Atlantic and South Atlantic basins (Degens et al., 1986; Forster et al., 2008). Our geochemical grain size proxies (i.e., $\mathrm{Si} / \mathrm{Al}$ and $\mathrm{Zr} / \mathrm{Al}$ ratios), however, indicate a homogenous grain size among all investigated shale samples with a markedly higher abundance of fine-grained siliciclastic material compared to sandstones (Fig. 3b). These observations and the good reproducibility of global $\delta^{13} \mathrm{C}$ variations recorded in black shales at Site 361 (Fig. 2b; Dummann et al., 2020) suggest that both black shale types are of hemipelagic origin.
Immobile trace element and REE data suggest that high TOC-low TOC alternations were accompanied by consistent changes in sediment provenance, which we attribute to changes in sediment routing and weathering regime on the proximal southern African continent. Similar to today, sediments accumulating in the deep Cape Basin were most likely transported to the Southwest African shelf by west-flowing river systems (De Wit, 1999; Dingle and Hendry, 1984; Partridge and Maud, 1987). According to paleo-drainage reconstructions, one major sediment route may have been the paleo-Karoo River, which entered the South Atlantic close to the modern Olifants River mouth in close proximity to Site 361 (Fig. 4a; De Wit, 1999). Recent apatite fissiontrack analyses support these paleo-drainage reconstructions and date the incision of the paleo-Karoo River into coastal areas of southwestern Africa at $\sim 120$ to $\sim 110 \mathrm{Ma}$ (Kounov et al., 2008), implying active river input to the Aptian Cape Basin. We consider three potential sediment source regions, representing the major geological provinces of the southern African continent (Fig. 4a): (1) Paleozoic to Early Mesozoic sediments from the Karoo and Cape supergroup, mainly located in the southwest and central part of southern Africa; (2) Jurassic volcanics related to the Karoo large igneous province, capping and intervening the Karoo supergroup in the east and northeast; and (3) Archean to Proterozoic sedimentary, volcanic, and metamorphic rocks of the Kaapvaal Craton, located in the northeast. The geochemical composition of potential sediment source regions is presented in Fig. 4c-e. Due to the complex geology of the Kaapvaal Craton and related intracratonic sediment sequences, we also included geochemical data of river bed sediments from modern rivers draining the Kaapvaal Craton, reflecting a more integrated signal (Garzanti et al., 2014).

Trace element discrimination plots suggest that Paleozoic sediments from the Karoo and Cape supergroup were the dominant weathering source of low-TOC black shales (Fig. 4c-e). This indicates a minor contribution from the Kaapvaal Craton and Karoo volcanics in the east and northeast, which display more mafic geochemical signatures, as indicated by lower $\mathrm{Th} / \mathrm{Sc}, \mathrm{Zr} / \mathrm{Sc}, \mathrm{La} / \mathrm{Sc}$, higher $\mathrm{Ti} / \mathrm{Zr}$ (Fig. 4c, d) and light REE depletion (REE characteristics of the Kaapvaal Craton are approximated by average Archean upper crust composition; Fig. 4e). Hence, we propose a dominant sediment input from Paleozoic source regions located along the coast in the west and southwest, with a minor contribution from mafic rocks further inland. Similar coastal regions have been inferred as the source region of turbiditic sediments at Site 361 (Natland, 1978). This may indicate that sediment input during low-TOC background sedimentation predominantly originated from areas located west of the escarpment (Fig. 4a), which today represents a major drainage divide that possibly already existed during the Early Cretaceous (Moore et al., 2009).

In contrast, trace element and REE compositions of highTOC black shales support a shift to more mafic signatures, 
typical for the Kaapvaal Craton and/or Karoo volcanics (Fig. 4c-e), suggesting enhanced sediment supply from the north and northeast (Fig. 4a). These data indicate a stronger sediment supply from areas located in the continent's interior relative to more coastal areas. Based on this trend, we propose that the shift in provenance from low- to high-TOC black shales reflects enhanced moisture supply to the continent's interior, augmenting river run-off in the upstream regions of west-flowing river systems (e.g., the paleo-Karoo River) and/or increasing chemical weathering intensity of basaltic rocks.

High-TOC black shales display overall high $\mathrm{K} / \mathrm{Al}$ ratios of $\sim 0.4$ (Fig. 2d), characteristic for illite (Fig. 4b; Weaver and Pollard, 1973). Consistent with their more mafic trace element signature, the Kaapvaal Craton and Karoo volcanics show $\mathrm{K} / \mathrm{Al}$ ratios substantially lower than those recorded in high-TOC black shales (Fig. 4b), indicating that higher K/Al ratios cannot be explained by the change in sediment provenance proposed for high-TOC black shales. Instead, we link $\mathrm{K} / \mathrm{Al}$ ratios to a change in the weathering intensity of $\mathrm{K}$ rich source regions along the coast (i.e., located west of the escarpment), including argillaceous sediments of the Karoo and Cape supergroups, Cape granites, and pan-African terranes of the Saldania Belt (Fig. 4a). Today, rivers draining these felsic rocks supply erosional inputs particularly rich in illite, which accounts for up to $90 \%$ of the total clay mineral assemblage in surface sediments near their river mouths (Birch, 1978). Quaternary sediment records also show that strong physical erosion and increased fluvial activity in these coastal source regions are reflected in enhanced input of $\mathrm{K}$ to the Southwest African shelf (Hahn et al., 2016) and probably the deep southern Cape Basin (Dickson et al., 2010). Assuming analogous mechanisms for the Cretaceous, we propose that the recorded increases in $\mathrm{K} / \mathrm{Al}$ ratios at Site 361 reflect periods of strong physical erosion of coastal K-rich source regions and riverine discharge to the Cape Basin. Supporting evidence comes from the good agreement of $\mathrm{K} / \mathrm{Al}$ ratios of high-TOC black shales and unweathered Karoo sediments (Fig. 4b), suggesting efficient bedrock erosion with minor alteration of the sediment's chemical composition by weathering during transport from source to sink.

Based on above lines of evidence, we propose that highTOC black shales were deposited during episodes of enhanced precipitation and strong river run-off from the proximal southern African continent, which caused enhanced contribution of weathering inputs from the continent's interior and intensification of bedrock erosion along the coast.

\subsection{Climate simulations}

In order to test feedback mechanisms on OC burial in the young South Atlantic basin, we modeled atmospheric and oceanographic circulation changes, specifically changes in wind-driven upwelling and continental hydrology (i.e., precipitation and total run-off) in response to orbital variations and $p \mathrm{CO}_{2}$ changes. Our model results indicate that Site 361 and the southern African continent were located within the humid austral westerly wind belt (Fig. 10a). Even though the strong north-south gradient in annual mean precipitation across Africa makes this result sensitive to the applied paleogeography, the paleo-climatic setting of southern Africa simulated in our model is consistent with previous GCM experiments (Chaboureau et al., 2012). It is further supported by the Early Cretaceous distribution of climate-sensitive deposits on the African continent, which is characterized by a dominance of evaporites north of a paleo-latitude of $\sim 40^{\circ} \mathrm{S}$ and coal deposits south of $\sim 40^{\circ} \mathrm{S}$, reflecting overall arid and humid conditions, respectively (Fig. 1; Boucot et al., 2013; Chumakov et al., 1995). This distribution implies that the descending limb of the southern paleo-Hadley cell separating the subtropical arid climate belt and the midlatitude humid climate belt was located north of Site 361 (Boucot et al., 2013; Chumakov et al., 1995). In accordance with this pattern, the simulated zonal mean edge of the Southern Hemisphere Hadley cell (defined as the latitude of the first zero crossing of the atmospheric mass stream function at the $500 \mathrm{hPa}$ level) is located at around 31 and $32^{\circ} \mathrm{S}$ for the 600 and $1200 \mathrm{ppm}$ experiments, respectively. This position is consistent with sparse geochemical data from Early Cretaceous (Albian) black shale sections from DSDP Site 530 in the Angola Basin and DSDP Site 511 on the Falkland Plateau at paleo-latitudes of $\sim 37$ and $\sim 58^{\circ} \mathrm{S}$, respectively (Wagner et al., 2013).

In contrast to the modern location along the coast of southwestern Africa, which is strongly influenced by the Benguela upwelling system, our simulations indicate no large-scale upwelling system along the Southwest African margin during the Aptian (Fig. S4 in Supplement file S4). We note, however, that we cannot rule out small coastal upwelling cells on scales below the horizontal model resolution of $\sim 200 \mathrm{~km}$. The absence of large-scale upwelling is a direct consequence of the more poleward position of the southern tip of Africa in the Early Cretaceous and the associated change in the dominant large-scale wind regime. While the present-day Benguela upwelling is driven by the prevailing southeasterly trade winds under the subtropical limp of the Hadley cell, the more southern position of the African continent during the Aptian leads to the predominance of the midlatitude westerlies. An eastern boundary upwelling system is, however, simulated further to the north in the Angola Basin, even though its strength would have been limited by the dimensions of the small basin. Based on these results, we conclude that coastal upwelling had a negligible impact on the magnitude of OC burial at Site 361.

Our simulations further indicate minor alterations in continental hydrology in response to changes in atmospheric $p \mathrm{CO}_{2}$ levels (at a constant orbital configurations). At $600 \mathrm{ppm} p \mathrm{CO}_{2}$, annual mean precipitation over southern Africa (i.e., in an area we consider representative for the catchment area based on our sediment provenance assess- 

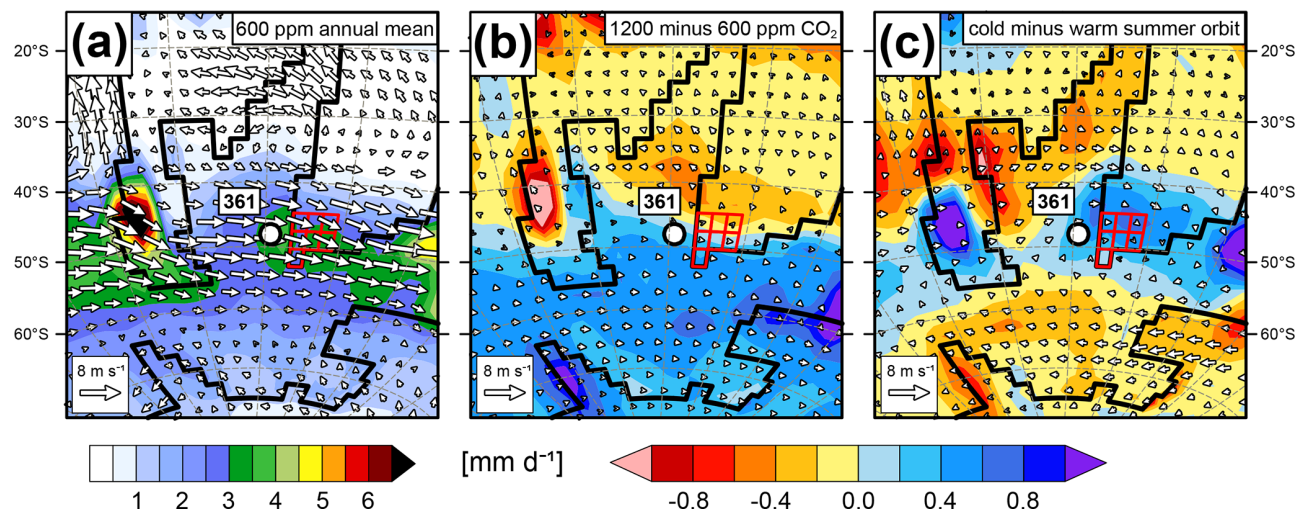

Figure 10. Large-scale atmospheric circulation and climate sensitivity of the study region: (a) simulated annual mean surface wind and precipitation at $600 \mathrm{ppm} \mathrm{pCO}_{2}$ and modern orbital configuration, (b) mean annual wind and precipitation changes due to a doubling of atmospheric $p \mathrm{CO}_{2}$ (constant orbital configuration), and (c) mean annual wind and precipitation changes related to orbital forcing (i.e., difference between cold and warm summer orbital configuration at $600 \mathrm{ppm} p \mathrm{CO}_{2}$ ). Highlighted grid points show the proposed catchment area. For more details on the modeling data, the reader is referred to Supplement file S4.
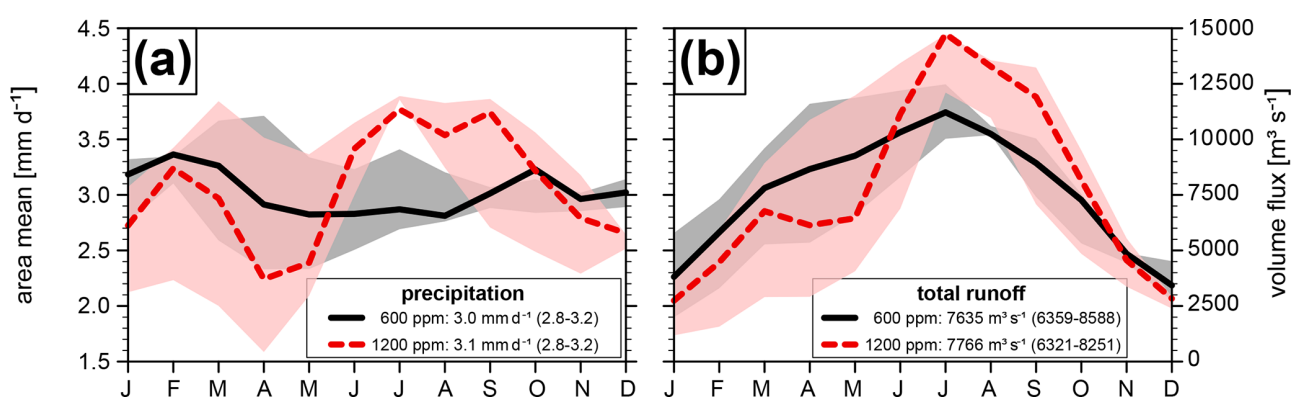

Figure 11. Annual cycle of (a) simulated precipitation and (b) total run-off averaged or integrated over the $\sim 450000 \mathrm{~km}^{2}$ large catchment

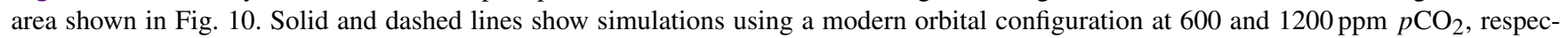
tively. Red and grey shadings represent precipitation and run-off ranges related to changes in orbital configuration at 600 and $1200 \mathrm{ppm}$ $p \mathrm{CO}_{2}$, respectively. Annual means for modern orbit simulations are provided in legends. Results for the cold summer orbit (i.e., maximum precipitation and run-off) and warm summer orbit (i.e., minimum precipitation and run-off) simulations are listed in parentheses.

ment; Fig. 10a) amounts to $3 \mathrm{~mm} \mathrm{~d}^{-1}$. A doubling of atmospheric $p \mathrm{CO}_{2}$ leads to overall higher precipitation south of Site 361 but drier conditions in the subtropical regions further north (Fig. 10b). This is in line with an enhanced hydrological cycle as a consequence of increased atmospheric $p \mathrm{CO}_{2}$ and global mean temperature (Held and Soden, 2006). As southern Africa is influenced by both regional aridification in its subtropical northern part and enhanced precipitation to the south, annual mean rainfall averaged over the proposed catchment area only increases by $1 \%$ between both simulations (Fig. 11a). However, we note that the doubling in $p \mathrm{CO}_{2}$ leads to a more pronounced seasonal cycle in the local rainfall (Figs. 11a and S5 in Supplement file S4) with reduced precipitation in austral summer (i.e., November-May) and an increase during austral winter (i.e., June-August).

In contrast, changes in orbital configuration exert a more profound control on continental hydrology over southern Africa. The cold summer orbit (i.e., 22.0 $0^{\circ}$ obliquity, perihelion during southern winter solstice) is associated with an increase of annual mean precipitation of $14 \%$ over the proposed catchment area (Figs. 10c and 11a) compared to the warm summer orbit $\left(24.5^{\circ}\right.$ obliquity, perihelion during southern summer solstice), which causes an increase in total annual run-off of $31 \%-35 \%$ (Fig. 11b). This disproportional increase in run-off relative to precipitation may in part be related to the colder summer temperatures $\left(\sim 5^{\circ} \mathrm{C}\right.$ difference between both orbital configurations during February), which causes a reduced evaporation of precipitation. Highest seasonal variability in total run-off is simulated during March to May (Fig. 11b) with fluxes 2 to 3 times higher for the cold summer orbit. In warm summer orbit simulations, precipitation is particularly strong along the southwestern coast of Africa (Figs. S6 and S7 in Supplement file S4), implying that sediment production and mobilization predominantly occurred in coastal areas, which is consistent with provenance data from low-TOC black shales. Increased precipitation associated with a cold summer orbit is not limited to the coastal regions but is also simulated further inland, 
with the highest variability during austral summer and autumn (Figs. S6 and S7 in Supplement file S4). We note that the large spatial extent of the enhanced moisture supply reduces the influence of uncertainties in the exact placement of the proposed catchment area for the significance of our results. Importantly, we show that the simulated run-off sensitivity to changes in the orbital parameters is very similar during low and high atmospheric $p \mathrm{CO}_{2}$ model runs (Figs. 11b, S6 and S7 in Supplement file S4), which suggests a similar response of continental hydrology to orbital forcing during different parts of the Aptian (i.e., before, during, and after OAE 1a).

\subsection{Depositional model for OC burial}

Internal heterogeneities in OC quantity and composition of Early Aptian black shales at Site 361, reflected in alternations between high-TOC and low-TOC intervals, suggest recurrent modulations of OC burial on timescales well below 1 Myr. Geochemical characteristics of all high-TOC intervals at Site 361 imply comparable depositional conditions with regard to paleo-redox conditions, OC source, and sediment provenance. High-TOC black shales were deposited during episodes of enhanced production and preservation of marine $\mathrm{OC}$ under anoxic-euxinic conditions, accompanied by changes in provenance and weathering state of sediments delivered from the proximal southern African continent. The latter are interpreted to reflect an expansion of the catchment area in response to enhanced precipitation in the continent's interior and intense bedrock erosion along the coast due to increased river run-off. Based on our GCM results, we propose that orbitally driven fluctuations in continental hydrology (i.e., precipitation and run-off), in particular minima in obliquity and a perihelion during southern winter solstice causing colder summers, triggered the episodic recurrence of conditions conducive to enhanced burial of OC in the Cape Basin. Our results indicate a similar response of continental hydrology to orbital forcing at 600 and $1200 \mathrm{ppm}$, which may explain the similar OC burial response during all high-TOC intervals before, during, and after OAE 1a. Unfortunately, the incomplete stratigraphic coverage at Site 361 prevents us from constraining the timing, duration, and pacing of highTOC intervals and their link to orbital forcing. We therefore suggest establishing an orbital chronology for the Early Cretaceous sedimentary record of the Cape Basin to test our hypothesis once new, high-resolution sediment records from the study area become available.

\subsection{Wider implications}

Our study re-emphasizes that ocean basins emerging during the break-up of super-continents provided favorable conditions for enhanced OC burial through basin geometries promoting hydrographic isolation and a close coupling of atmosphere-land-ocean interactions. The results of this study further suggest that deep marine environments (i.e., $>2000 \mathrm{~m}$ ) along the continental margins of emerging ocean basins were sensitive to changes in nutrient fluxes from the continent. In case of the Cape Basin, this close landocean coupling is supported by our model results, which suggest that no large-scale ocean upwelling occurred along the Southwest African margin during the Aptian (Fig. S4 in Supplement file S4). One underlying reason for this higher sensitivity to across-shelf nutrient transport in young ocean basins may have been very narrow shelves, permitting substantial and almost direct escape of continent-derived nutrients and mineral matter to the deep ocean, which is supported by recent modeling data (Sharples et al., 2017; Izett and Fennel, 2018). Shelves in emerging ocean basins are generally narrow and underdeveloped, as some time is required for drainage systems to mature and for marginal strata to accumulate (Ravnås and Steel, 1998; Trabucho Alexandre et al., 2012). Consistent with these characteristics, turbiditic sandstones deposited at Site 361 lack re-deposited benthic organisms, which has been interpreted to reflect short residence times or even no intermediate storage in near-shore or shelf environments.

Our GCM results further indicate that southern Africa was located south of the descending limb of the Hadley cell and influenced by the austral westerlies. These results serve to constrain the position of the descending limb of the southern Hadley cell during the Early Cretaceous, which had proven difficult based on previously available data and coring sites (Wagner et al., 2013). The results suggest a close coupling of marine OC burial dynamics and orbitally paced atmospheric processes operating beneath the Ferrell cell, similar to what has been observed at sites beneath the Hadley cell (Wagner et al., 2013).

\section{Conclusions}

In this study, we reconstruct the evolution of paleo-redox conditions, OC composition, and sediment provenance in the Aptian-Albian Cape Basin based on $\mathrm{Fe}, \mathrm{S}$, and TOC systematics; distribution of redox-sensitive trace metals; lipid biomarker data; and the inorganic geochemical composition of sediments at Site 361. The results demonstrate that hydrographic restriction of the Cape Basin during the Early Aptian generally promoted oxygen deficiency in the deeper water column, favoring the deposition of extensive black shales. The richness and composition of OC in Early Aptian black shales at Site 361 varied on timescales $<1 \mathrm{Myr}$, documented in high-TOC (6\%-20\%) black shale intervals, which occur repetitively throughout the records. These high-TOC intervals were the result of enhanced burial of marine OC deposited under anoxic and probably euxinic bottom water conditions. Changes in OC burial were tightly coupled to fluctuations in river run-off from the southern African continent, suggesting orbitally driven aridity and humidity variations 
in the midlatitude humid climate zone as a primary forcing mechanism. Based on this tight coupling of biogeochemical cycling in the deep (>2000 m) Cape Basin and climateland-ocean interactions, we propose that narrow immature continental shelves in the emerging ocean basin facilitated a more efficient land-open ocean nutrient transfer. By Late Aptian-Albian times, the abatement of hydrographic restriction of the Cape Basin terminated the conditions favorable for OC preservation, as reflected in a two-step increase in bottom water oxygenation and concomitant decreases in OC burial, indicating that intensified deep water ventilation decreased the sensitivity of the basin to climatic perturbations. This leads us to conclude that climatic fluctuations alone without the appropriate basin configuration for OC preservation were insufficient to generate enhanced $\mathrm{OC}$ burial.

Data availability. All original data used in this publication will be made available through the PANGAEA ${ }^{\circledR}$ Data Publisher for Earth and Environmental Science (https://www.pangaea.de/, last access: 17 February 2021).

Supplement. The supplement related to this article is available online at: https://doi.org/10.5194/cp-17-469-2021-supplement.

Author contributions. PH, SF, JOH, JR, and TW were involved in the conceptualization of this study and acquired funding. WD and PH conducted XRF analyses. Biomarker analysis were conducted by WD under the supervision of SK, CH, and JR. ICP-MS data were acquired by ML under the supervision of HUK. SS and SF carried out the modeling experiments. WD integrated the data and wrote the manuscript with contributions from all authors.

Competing interests. The authors declare that they have no conflict of interest.

Acknowledgements. We thank Nicole Mantke and Simon Kalinowski for their support in proxy data acquisition and Tamara Mai for her help during sampling of Site 361. Model integrations were conducted at the Computing Center of Kiel University. We thank Janine Blöhdorn for generating most of the Cretaceous KCM boundary conditions and Stefan Hagemann for constructing the parameters for the hydrological discharge model. This research used samples provided by the Deep Sea Drilling Project.

Financial support. This research has been supported by the Deutsche Forschungsgemeinschaft (grant nos. HO2188/9 and HE3521/6).

Review statement. This paper was edited by Yannick Donnadieu and reviewed by Alexandre Pohl and one anonymous referee.

\section{References}

Algeo, T. J. and Maynard, J. B.: Trace-element behavior and redox facies in core shales of Upper Pennsylvanian Kansas-type cyclothems, Chem. Geol., 206, 289-318, https://doi.org/10.1016/j.chemgeo.2003.12.009, 2004.

Algeo, T. J. and Maynard, J. B.: Trace-metal covariation as a guide to water-mass conditions in ancient anoxic marine environments, Geosphere, 4, 872-887, https://doi.org/10.1130/GES00174.1, 2008.

Arthur, M. A. and Natland, J. H.: Carbonaceous sediments in the North and South Atlantic: The Role of Salinity in Stable Stratification of Early Cretaceous Basins, in: Deep Drilling Results in the Atlantic Ocean: Continental Margins and Paleoenvironment, edited by: Talwani, M., Hay, W. W., and Ryan, W. B. F., Maurice Ewing Series, 3, American Geophysical Union, Washington DC (USA), 375-401, https://doi.org/10.1029/me003p0375, 1979.

Arthur, M. A. and Sageman, B. B.: Marine Black Shales: Depositional Mechanisms and Environments of Ancient Deposits, Annu. Rev. Earth Planet. Sci., 22, 499-551, https://doi.org/10.1146/annurev.ea.22.050194.002435, 1994.

Beckmann, B., Flögel, S., Hofmann, P., Schulz, M., and Wagner, T.: Orbital forcing of Cretaceous river discharge in tropical Africa and ocean response, Nature, 437, 241-244, https://doi.org/10.1038/nature03976, 2005.

Behrooz, L., Naafs, B. D. A., Dickson, A. J., Love, G. D., Batenburg, S. J., and Pancost, R. D.: Astronomically driven variations in depositional environments in the South Atlantic during the Early Cretaceous, Paleoceanogr. Paleoclim., 33, 894-912, https://doi.org/10.1029/2018pa003338, 2018.

Berger, A.: Long-term variations of daily insolation and Quaternary climatic changes, J. Atmos. Sci., 35, 2362-2367, https://doi.org/10.1175/15200469(1978)035<2362:LTVODI>2.0.CO;2, 1978.

Berner, R. A. and Raiswell, R.: Burial of organic carbon and pyrite sulfur in sediments over Phanerozoic time: a new theory, Geochim. Cosmochim. Ac., 47, 855-862, https://doi.org/10.1016/0016-7037(83)90151-5, 1983.

Bhatia, M. R. and Crook, K. A.: Trace element characteristics of graywackes and tectonic setting discrimination of sedimentary basins, Contrib. Mineral. Petr., 92, 181-193, https://doi.org/10.1007/bf00375292, 1986.

Birch, G.: The distribution of clay minerals on the continental margin off the West Coast of South Africa, T. Geol. Soc. South Africa, 81, 23-24, 1978.

Böning, P., Shaw, T., Pahnke, K., and Brumsack, H.-J.: Nickel as indicator of fresh organic matter in upwelling sediments, Geochim. Cosmochim. Ac., 162, 99-108, https://doi.org/10.1016/j.gca.2015.04.027, 2015.

Boucot, A. J., Xu, C., Scotese, C. R., and Morley, R. J.: Phanerozoic Paleoclimate: An Atlas of Lithologic Indicators of Climate, SEPM Society for Sedimentary Geology, Tulsa, USA, 30 pp., https://doi.org/10.2110/sepmcsp.11, 2013.

Bralower, T. J. and Thierstein, H. R.: Low productivity and slow deep-water circulation in mid-Cretaceous oceans, Geology, 12, 614-618, https://doi.org/10.1130/00917613(1984)12<614:LPASDC>2.0.CO;2, 1984. 
Bray, E. and Evans, E.: Distribution of n-paraffins as a clue to recognition of source beds, Geochim. Cosmochim. Ac., 22, 215, https://doi.org/10.1016/0016-7037(61)90069-2, 1961.

Cao, W., Zahirovic, S., Flament, N., Williams, S., Golonka, J., and Müller, R. D.: Improving global paleogeography since the late Paleozoic using paleobiology, Biogeosciences, 14, 5425-5439, https://doi.org/10.5194/bg-14-5425-2017, 2017.

Cao, W., Williams, S., Flament, N., Zahirovic, S., Scotese, C., and Müller, R. D.: Palaeolatitudinal distribution of lithologic indicators of climate in a palaeogeographic framework, Geol. Mag., 156, 331-354, https://doi.org/10.1017/s0016756818000110, 2019.

Caron, D. A.: The rise of Rhizaria, Nature, 532, 444-445, https://doi.org/10.1038/nature17892, 2016.

Chaboureau, A.-C., Donnadieu, Y., Sepulchre, P., Robin, C., Guillocheau, F., and Rohais, S.: The Aptian evaporites of the South Atlantic: a climatic paradox?, Clim. Past, 8, 1047-1058, https://doi.org/10.5194/cp-8-1047-2012, 2012.

Chumakov, N. M., Zharkov, M. A., Herman, A. B., Doludenko, M. P., Kalandadze, N. N., Lebedev, E. L., Ponomarenko, A. G., and Rautian, A. S.: Climatic belts of the mid-Cretaceous time, Stratigr. Geol. Correl., 3, 241-260, 1995.

Coccioni, R., Erba, E., and Premoli-Silva, I.: Barremian-Aptian calcareous plankton biostratigraphy from the Gorgo Cerbara section (Marche, central Italy) and implications for plankton evolution, Cretaceous Res., 13, 517-537, https://doi.org/10.1016/01956671(92)90015-I, 1992.

Croudace, I. W. and Rothwell, R. G.: Micro-XRF Studies of Sediment Cores: Applications of a non-destructive tool for the environmental sciences, Springer, Heidelberg, Germany, 650 pp., 2015.

Crowley, T. J., Yip, K. J. J., and Baum, S. K.: Milankovitch cycles and Carboniferous climate, Geophys. Res. Lett., 20, 1175-1178, https://doi.org/10.1029/93GL01119, 1993.

Dean, W. E., and Arthur, M. A.: Iron-sulfur-carbon relationships in organic-carbon-rich sequences I: Cretaceous Western Interior Seaway, Am. J. Sci., 289, 708-743, https://doi.org/10.2475/ajs.289.6.708, 1989.

Degens, E. T., Emeis, K. C., Mycke, B., and Wiesner, M. G.: Turbidites, the principal mechanism yielding black shales in the early deep Atlantic Ocean, in: North Atlantic Palaeoceanography, edited by: Summerhayes, C. P. and Shackleton, N. J., Special Publications, 21, Geological Society of London, London, UK, 361-376, https://doi.org/10.1144/gsl.sp.1986.021.01.26, 1986.

De Wit, M.: Post-Gondwana drainage and the development of diamond placers in western South Africa, Econ. Geol., 94, 721-740, https://doi.org/10.2113/gsecongeo.94.5.721, 1999.

Dickson, A. J., Leng, M. J., Maslin, M. A., and Röhl, U.: Oceanic, atmospheric and ice-sheet forcing of South East Atlantic Ocean productivity and South African monsoon intensity during MIS-12 to 10, Quaternary Sci. Rev., 29, 3936-3947, https://doi.org/10.1016/j.quascirev.2010.09.014, 2010.

Dingle, R. V. and Hendry, Q. B.: Late Mesozoic and Tertiary sediment supply to the eastern Cape Basin (SE Atlantic) and palaeodrainage systems in southwestern Africa, Mar. Geol., 56, 13-26, 1984.

Donnadieu, Y., Pucéat, E., Moiroud, M., Guillocheau, F., and Deconinck, J.-F.: A better-ventilated ocean triggered by Late Cre- taceous changes in continental configuration, Nat. Commun., 7, 10316, https://doi.org/10.1038/ncomms10316, 2016.

Dulski, P.: Reference materials for geochemical studies: New analytical data by ICP-MS and critical discussion of reference values, Geostandard. Newslett., 25, 87-125, https://doi.org/10.1111/j.1751-908x.2001.tb00790.x, 2001.

Dummann, W., Steinig, S., Hofmann, P., Flögel, S., Osborne, A. H., Frank, M., Herrle, J. O., Bretschneider, L., Sheward, R. M., and Wagner, T.: The impact of Early Cretaceous gateway evolution on ocean circulation and organic carbon burial in the emerging South Atlantic and Southern Ocean basins, Earth Planet. Sci. Lett., 530, 115890, https://doi.org/10.1016/j.epsl.2019.115890, 2020.

Eglinton, G. and Hamilton, R. J.: Leaf epicuticular waxes, Science, 156, 1322-1335, https://doi.org/10.1126/science.156.3780.1322, 1967.

Erba, E.: Nannofossils and superplumes: the early Aptian "nannoconid crisis", Paleoceanography, 9, 483-501, https://doi.org/10.1029/94PA00258, 1994.

Forster, A., Kuypers, M. M., Turgeon, S. C., Brumsack, H.J., Petrizzo, M. R., and Sinninghe Damsté, J. S.: The Cenomanian/Turonian oceanic anoxic event in the South Atlantic: New insights from a geochemical study of DSDP Site 530A, Palaeogeogr., Palaeoclim. Palaeoecol., 267, 256-283, https://doi.org/10.1016/j.palaeo.2008.07.006, 2008.

Garver, J. I., Royce, P. R., and Smick, T. A.: Chromium and nickel in shale of the Taconic foreland; a case study for the provenance of fine-grained sediments with an ultramafic source, J. Sediment. Res., 66, 100-106, https://doi.org/10.1306/d42682c52b26-11d7-8648000102c1865d, 1996.

Garzanti, E., Padoan, M., Setti, M., López-Galindo, A., and Villa, I. M.: Provenance versus weathering control on the composition of tropical river mud (southern Africa), Chem. Geol., 366, 61-74, https://doi.org/10.1016/j.chemgeo.2013.12.016, 2014.

Govindaraju, K.: 1994 Compilation of working values and sample description for 383 geostandards, Geostandard. Newslett., 18, 1158, https://doi.org/10.1046/j.1365-2494.1998.53202081.x-i1, 1994.

Gradstein, F. M., Ogg, J. G., Schmitz, M., and Ogg, G.: The Geologic Time Scale 2012, Elsevier, Amsterdam, the Netherlands, 1176 pp., https://doi.org/10.1016/c2011-1-08249-8, 2012.

Hahn, A., Compton, J. S., Meyer-Jacob, C., Kirsten, K. L., Lucasssen, F., Mayo, M. P., Schefuß, E., and Zabel, M.: Holocene paleo-climatic record from the South African Namaqualand mudbelt: A source to sink approach, Quaternary Int., 404, 121135, https://doi.org/10.1016/j.quaint.2015.10.017, 2016.

Han, J. and Calvin, M.: Hydrocarbon distribution of algae and bacteria, and microbiological activity in sediments, P. Natl. Acad. Sci. USA, 64, 436-443, https://doi.org/10.1073/pnas.64.2.436, 1969.

Hartwig, A., di Primio, R., Anka, Z., and Horsfield, B.: Source rock characteristics and compositional kinetic models of Cretaceous organic rich black shales offshore southwestern Africa, Org. Geochem., 51, 17-34, https://doi.org/10.1016/j.orggeochem.2012.07.008, 2012.

Held, I. M. and Soden, B. J.: Robust responses of the hydrological cycle to global warming, J. Climate, 19, 5686-5699, https://doi.org/10.1175/jcli3990.1, 2006. 
Herbin, J. P., Muller, C., de Graciansky, P. C., Jacquin, T., Magniez-Jannin, F., and Unternehr, P.: Cretaceous anoxic events in the South Atlantic, Rev. Bras. Geoci., 17, 92-99, https://doi.org/10.25249/0375-7536.19879299, 1987.

Herrle, J. O., Pross, J., Friedrich, O., Kößler, P., and Hemleben, C.: Forcing mechanisms for mid-Cretaceous black shale formation: evidence from the Upper Aptian and Lower Albian of the Vocontian Basin (SE France), Palaeogeogr. Palaeoclimatol. Palaeoecol., 190, 399-426, https://doi.org/10.1016/S00310182(02)00616-8, 2003.

Hofmann, P. and Wagner, T.: ITCZ controls on Late Cretaceous black shale sedimentation in the tropical Atlantic Ocean, Paleoceanogr. Paleoclimatol., 26, PA4223, https://doi.org/10.1029/2011pa002154, 2011.

Huang, W.-Y. and Meinschein, W.: Sterols as ecological indicators, Geochim. Cosmochim. Ac., 43, 739-745, https://doi.org/10.1016/0016-7037(79)90257-6, 1979.

Izett, J. G. and Fennel, K.: Estimating the Cross-Shelf Export of Riverine Materials: Part 1. General Relationships From an Idealized Numerical Model, Global Biogeochem. Cy., 32, 160-175, https://doi.org/10.1002/2017gb005667, 2018.

Jacquin, T. and De Graciansky, P. C.: Cyclic fluctuations of anoxia during Cretaceous time in the South Atlantic Ocean, Mar. Petrol. Geol., 5, 359-369, 1988.

Jenkyns, H. C.: Geochemistry of oceanic anoxic events, Geochem. Geophys. Geosy., 11, 1-30, https://doi.org/10.1029/2009gc002788, 2010.

Jing, D. and Bainian, S.: Early Cretaceous atmospheric CO2 estimates based on stomatal index of Pseudofrenelopsis papillosa (Cheirolepidiaceae) from southeast China, Cretaceous Res., 85, 232-242, https://doi.org/10.1016/j.cretres.2017.08.011, 2018.

Kagami, H.: Sedimentary features of Cape Basin and Angola Basin sediments, DSDP Leg 40, Initial Reports of the Deep Sea Drilling Project, 40, 525, https://doi.org/10.2973/dsdp.proc.40.108.1978, 1978.

Kolonic, S., Wagner, T., Forster, A., Sinninghe Damsté, J. S., Walsworth-Bell, B., Erba, E., Turgeon, S., Brumsack, H. J., Chellai, E. H., and Tsikos, H.: Black shale deposition on the northwest African Shelf during the Cenomanian/Turonian oceanic anoxic event: Climate coupling and global organic carbon burial, Paleoceanogr., 20, PA1006, https://doi.org/10.1029/2003pa000950, 2005.

Koopmans, M. P., Köster, J., Van Kaam-Peters, H. M. E., Kenig, F., Schouten, S., Hartgers, W. A., de Leeuw, J. W., and Sinninghe Damsté, J. S.: Diagenetic and catagenetic products of isorenieratene: molecular indicators for photic zone anoxia, Geochim. Cosmochim. Ac., 60, 4467-4496, https://doi.org/10.1016/s00167037(96)00238-4, 1996.

Kounov, A., Viola, G., De Wit, M., and Andreoli, M.: A Mid Cretaceous paleo-Karoo River valley across the Knersvlakte plain (northwestern coast of South Africa): Evidence from apatite fission-track analysis, S. Afr. J. Geol., 111, 409-420, https://doi.org/10.2113/gssajg.111.4.409, 2008.

Lampitt, R., Salter, I., and Johns, D.: Radiolaria: Major exporters of organic carbon to the deep ocean, Global Biogeochem. Cy., 23, GB1010, https://doi.org/10.1029/2008gb003221, 2009.

Laskar, J., Fienga, A., Gastineau, M., and Manche, H.: La2010: a new orbital solution for the long-term motion of the Earth,
Astron. Astrophys., 532, A89, https://doi.org/10.1051/00046361/201116836, 2011.

Leventhal, J. S.: An interpretation of carbon and sulfur relationships in Black Sea sediments as indicators of environments of deposition, Geochim. Cosmochim. Ac., 47, 133-137, https://doi.org/10.1016/0016-7037(83)90097-2, 1983.

Little, S. H., Vance, D., Lyons, T. W., and McManus, J.: Controls on trace metal authigenic enrichment in reducing sediments: insights from modern oxygen-deficient settings, Am. J. Sci., 315, 77-119, https://doi.org/10.2475/02.2015.01, 2015.

Macdonald, D., Gomez-Perez, I., Franzese, J., Spalletti, L., Lawver, L., Gahagan, L., Dalziel, I., Thomas, C., Trewin, N., and Hole, M.: Mesozoic break-up of SW Gondwana: implications for regional hydrocarbon potential of the southern South Atlantic, Mar. Petrol. Geol., 20, 287-308, https://doi.org/10.1016/s02648172(03)00045-x, 2003.

Madec, G. V.: NEMO Ocean engine, Note du Pôle de modélisation No. 27, Institut Pierre-Simon Laplace (IPSL), Paris, France, 2008.

Matthews, K. J., Maloney, K. T., Zahirovic, S., Williams, S. E., Seton, M., and Müller, R. D.: Global plate boundary evolution and kinematics since the late Paleozoic, Global Planet. Change, 146, 226-250, https://doi.org/10.1016/j.gloplacha.2016.10.002, 2016.

McAnena, A., Flögel, S., Hofmann, P., Herrle, J. O., Griesand, A., Pross, J., Talbot, H. M., Rethemeyer, J., Wallmann, K., and Wagner, T.: Atlantic cooling associated with a marine biotic crisis during the mid-Cretaceous period, Nat. Geosci., 6, 558-561, https://doi.org/10.1038/ngeo1850, 2013.

McLennan, S., Hemming, S., McDaniel, D., and Hanson, G.: Geochemical approaches to sedimentation, provenance, and tectonics, in: Processes Controlling the Composition of Clastic Sediments, edited by: Johnsson, M., and Basu, A., GSA Special Papers, 284, Geological Society of America, Boulder, USA, 21-40, https://doi.org/10.1130/spe284-p21, 1993.

Melguen, M.: Facies evolution, carbonate dissolution cycles in sediments from the eastern South Atlantic (DSDP Leg 40) since the Early Cretaceous, in: Initial Reports of the Deep Sea Drilling Project, Volume 40, edited by: Bolli, H. M. and Ryan, W. B. F., U.S. Government Printing Office, Washington, DC, USA, 9811024, https://doi.org/10.2973/dsdp.proc.40.129.1978, 1978.

Menegatti, A. P., Weissert, H., Brown, R. S., Tyson, R. V., Farrimond, P., Strasser, A., and Caron, M.: Highresolution $\delta^{13} \mathrm{C}$ stratigraphy through the early Aptian "Livello Selli" of the Alpine Tethys, Paleoceanogr., 13, 530-545, https://doi.org/10.1029/98pa01793, 1998.

Meyer, K. M. and Kump, L. R.: Oceanic Euxinia in Earth History: Causes and Consequences, Annu. Rev. Earth Planet. Sci., 36, 251-288, https://doi.org/10.1146/annurev.earth.36.031207.124256, 2008.

Moldowan, J. M., Seifert, W. K., and Gallegos, E. J.: Relationship between petroleum composition and depositional environment of petroleum source rocks, AAPG Bull., 69, 1255-1268, https://doi.org/10.1306/ad462bc8-16f7-11d7$8645000102 \mathrm{c} 1865 \mathrm{~d}, 1985$.

Moldowan, J. M., Fago, F. J., Lee, C. Y., Jacobson, S. R., Watt, D. S., Slougui, N. E., Jeganathan, A., and Young, D. C.: Sedimentary 24- $n$-Propylcholestanes, Molecular Fossils Diagnostic of Marine Algae, Science, 247, 309-312, https://doi.org/10.1126/science.247.4940.309, 1990. 
Moore, A., Blenkinsop, T., and Cotterill, F.: Southern African topography and erosion history: plumes or plate tectonics?, Terra Nova, 21, 310-315, https://doi.org/10.1111/j.13653121.2009.00887.x, 2009.

Naafs, B. D. A. and Pancost, R. D.: Environmental conditions in the South Atlantic (Angola Basin) during the Early Cretaceous, Org. Geochem., 76, 184-193, https://doi.org/10.1016/j.orggeochem.2014.08.005, 2014.

Naafs, B. D. A., Castro, J. M., De Gea, G. A., Quijano, M. L., Schmidt, D. N., and Pancost, R. D.: Gradual and sustained carbon dioxide release during Aptian Oceanic Anoxic Event 1a, Nat. Geosci., 9, 135-139, https://doi.org/10.1038/ngeo2627, 2016.

Natland, J. H.: Composition, provenance, and diagenesis of Cretaceous clastic sediments drilled on the Atlantic continental rise off Southern Africa, DSDP Site 361; implications for the early circulation of the South Atlantic, in: Initial Reports of the Deep Sea Drilling Project, Volume 40, edited by: Bolli, H. M. and Ryan, W. B. F., U.S. Government Printing Office, Washington, DC, USA, 1025-1061, https://doi.org/10.2973/dsdp.proc.40.130.1978, 1978.

Nettersheim, B. J., Brocks, J. J., Schwelm, A., Hope, J. M., Not, F., Lomas, M., Schmidt, C., Schiebel, R., Nowack, E. C., and De Deckker, P.: Putative sponge biomarkers in unicellular Rhizaria question an early rise of animals, Nat. Ecol. Evol., 3, 577, https://doi.org/10.1038/s41559-019-0806-5, 2019.

O’Brien, C. L., Robinson, S. A., Pancost, R. D., Sinninghe Damsté, J. S., Schouten, S., Lunt, D. J., Alsenz, H., Bornemann, A., Bottini, C., and Brassell, S. C.: Cretaceous sea-surface temperature evolution: Constraints from $\mathrm{TEX}_{86}$ and planktonic foraminiferal oxygen isotopes, Earth-Sci. Rev. 172, 224-247, https://doi.org/10.1130/abs/2018am-323378, 2017.

Park, W., Keenlyside, N., Latif, M., Ströh, A., Redler, R., Roeckner, E., and Madec, G.: Tropical Pacific climate and its response to global warming in the Kiel Climate Model, J. Climate, 22, 7192, https://doi.org/10.1175/2008jcli2261.1, 2009.

Partridge, T. C. and Maud, R. R.: Geomorphic evolution of southern Africa since the Mesozoic, S. Afr. J. Geol., 90, 179-208, 1987.

Pedersen, T. and Calvert, S.: Anoxia vs. Productivity: What Controls the Formation of Organic-Carbon-Rich Sediments and Sedimentary Rocks?, AAPG Bull., 74, 454-466, https://doi.org/10.1306/0c9b232b-1710-11d7$8645000102 \mathrm{c} 1865 \mathrm{~d}, 1990$.

Pérez-Díaz, L. and Eagles, G.: South Atlantic paleobathymetry since early Cretaceous, Sci. Rep.-UK, 7, 11819, https://doi.org/10.1038/s41598-017-11959-7, 2017.

Peters, K. E., Walters, C. C., and Moldowan, J. M.: The Biomarker Guide: Volume 2, Biomarkers and Isotopes in Petroleum Exploration and Earth History, Cambridge University Press, New York City, USA, 1155 pp., 2007.

Proto Decima, F., Medizza, F., and Todesco, L.: Southeastern Atlantic Leg 40 calcareous nannofossils, in: Initial Reports of the Deep Sea Drilling Project, Volume 40, edited by: Bolli, H. M. and Ryan, W. B. F., 40, US Government Printing Office, Washington, DC, USA, 571-634, 1978.

Raiswell, R., Buckley, F., Berner, R. A., and Anderson, T. F.: Degree of pyritization of iron as a paleoenvironmental indicator of bottom-water oxygenation, J. Sediment. Res., 58, 812-819, https://doi.org/10.1306/212f8e722b24-11d7-8648000102c1865d, 1988.
Ravnås, R. and Steel, R.: Architecture of marine rift-basin successions, AAPG Bulletin, 82, 110146, https://doi.org/10.1306/1d9bc3a9-172d-11d7$8645000102 \mathrm{c} 1865 \mathrm{~d}, 1998$.

Raynaud, J. F. and Robert, P.: Microscopical survey of organic matter from DSDP sites 361, 362, and 364, in: Initial reports of the Deep Sea Drilling Project, Volume 40, edited by: Bolli, H. M. and Ryan, W. B. F., US Government Printing Office, Washington, DC, USA, 663-669, https://doi.org/10.2973/dsdp.proc.38394041s.306.1978, 1978.

Roeckner, E., Bäuml, G., Bonaventura, L., Brokopf, R., Esch, M., Giorgetta, M., Hagemann, S., Kirchner, I., Kornblueh, L., Manzini, E., Rhodin, A., Schlese, U., Schulzweida, A., and Tompkins, A.: The atmospheric general circulation model ECHAM 5. PART I: Model description, Max Planck Institute for Meteorology, Hamburg (Germany), Report No. 349, 2003.

Schlanger, S. O. and Jenkyns, H. C.: Cretaceous oceanic anoxic events: causes and consequences, Geol. Mijnbouw, 55, 179-184, 1976.

Sewall, J. O., van de Wal, R. S. W., van der Zwan, K., van Oosterhout, C., Dijkstra, H. A., and Scotese, C. R.: Climate model boundary conditions for four Cretaceous time slices, Clim. Past, 3, 647-657, https://doi.org/10.5194/cp-3-647-2007, 2007.

Sharples, J., Middelburg, J. J., Fennel, K., and Jickells, T. D.: What proportion of riverine nutrients reaches the open ocean?, Global Biogeochem. Cy., 31, 39-58, https://doi.org/10.1002/2016gb005483, 2017.

Sinninghe Damsté, J. S., Kuypers, M. M. M., Schouten, S., Schulte, S., and Rullkötter, J.: The lycopane/C31 n-alkane ratio as a proxy to assess palaeoxicity during sediment deposition, Earth. Planet. Sc. Lett., 209, 215-226, https://doi.org/10.1016/s0012821x(03)00066-9, 2003.

Stein, R., Rullkötter, J., and Welte, D. H.: Accumulation of organic-carbon-rich sediments in the Late Jurassic and Cretaceous Atlantic Ocean-A synthesis, Chem. Geol., 56, 1-32, https://doi.org/10.1016/0009-2541(86)90107-5, 1986.

Steinig, S., Dummann, W., Park, W., Latif, M., Kusch, S., Hofmann, P., and Flögel, S.: Evidence for a regional warm bias in the Early Cretaceous TEX86 record, Earth Planet. Sc. Lett., 539, 116184, https://doi.org/10.1016/j.epsl.2020.116184, 2020.

The Shipboard Scientific Party: Cape Basin continental rise; Sites 360 and 361, in: Initial Reports of the Deep Sea Drilling Project, Volume 40, edited by: Bolli, H. M. and Ryan, W. B. F., US Government Printing Office, Washington, DC, USA, 29-182, https://doi.org/10.2973/dsdp.proc.40.102.1978, 1978.

Thiede, J. and Van Andel, T. H.: The paleoenvironment of anaerobic sediments in the late Mesozoic South Atlantic Ocean, Earth Planet. Sc. Lett., 33, 301-309, https://doi.org/10.1016/0012821x(77)90082-6, 1977.

Trabucho-Alexandre, J., Hay, W. W., and de Boer, P. L.: Phanerozoic environments of black shale deposition and the Wilson $\mathrm{Cy}$ cle, Solid Earth, 3, 29-42, https://doi.org/10.5194/se-3-29-2012, 2012.

Tribovillard, N., Algeo, T. J., Lyons, T., and Riboulleau, A.: Trace metals as paleoredox and paleoproductivity proxies: an update, Chem. Geol., 232, 12-32, https://doi.org/10.1016/j.chemgeo.2006.02.012, 2006.

Twining, B. S., Baines, S. B., Vogt, S., and Nelson, D. M.: Role of diatoms in nickel biogeochemistry 
in the ocean, Global Biogeochem. Cy., 26, GB4001, https://doi.org/10.1029/2011gb004233, 2012.

Tyson, R.: The "productivity versus preservation" controversy: cause, flaws, and resolution, in: The Deposition of OrganicCarbon-Rich Sediments: Models, Mechanisms, and Consequences, edited by: Harris, N., SEPM Special Publication, 82, SEPM Society for Sedimentary Geology, Tulsa, USA, 17-33, https://doi.org/10.2110/pec.05.82.0017, 2005.

Van Andel, T. H., Thiede, J., Sclater, J. G., and Hay, W. W.: Depositional history of the South Atlantic Ocean during the last 125 million years, J. Geol., 85, 651-698, https://doi.org/10.1086/628357, 1977.

Wagner, T. and Pletsch, T.: Tectono-sedimentary controls on Cretaceous black shale deposition along the opening Equatorial Atlantic Gateway (ODP Leg 159), in: The Oil and Gas Habitats of the South Atlantic, edited by: Cameron, N. R., Bate, R. H., and Clure, V. S., Special Publications, 153, Geological Society of London, London, UK, 241-265, https://doi.org/10.1144/GSL.SP.1999.153.01.15, 1999.

Wagner, T., Hofmann, P., and Flögel, S.: Marine black shale deposition and Hadley Cell dynamics: A conceptual framework for the Cretaceous Atlantic Ocean, Mar. Petrol. Geol., 43, 222-238, https://doi.org/10.1016/j.marpetgeo.2013.02.005, 2013.

Wanty, R. B. and Goldhaber, M. B.: Thermodynamics and kinetics of reactions involving vanadium in natural systems: Accumulation of vanadium in sedimentary rocks, Geochim. Cosmochim. Ac., 56, 1471-1483, https://doi.org/10.1016/00167037(92)90217-7, 1992.
Weaver, C. E. and Pollard, L. D.: The Chemistry of Clay Minerals, Developments in Sedimentology, 15, Elsevier, Amsterdam, the Netherlands, 212 pp., 1973.

Wedepohl, K. H.: Environmental influences on the chemical composition of shales and clays, Phys. Chem. Earth, 8, 307-333, https://doi.org/10.1016/0079-1946(71)90020-6, 1971.

Wedepohl, K. H.: The Composition of Earth's Upper Crust, Natural Cycles of Elements, Natural Resources, in: Metals and Their Compounds in the Environment, edited by: Merian, E., Anke, M., Ihnat, M., and Stoeppler, M., Wiley-VCH, Weinheim, Germany, 3-17, 2004.

Weissert, H., Lini, A., Föllmi, K. B., and Kuhn, O.: Correlation of Early Cretaceous carbon isotope stratigraphy and platform drowning events: a possible link?, Palaeogeogr. Palaeoclim. Palaeoecol., 137, 189-203, https://doi.org/10.1016/S00310182(97)00109-0, 1998.

Zimmerman, H. B., Boersma, A., and McCoy, F. W.: Carbonaceous sediments and palaeoenvironment of the Cretaceous South Atlantic Ocean, in: Marine Petroleum Source Rocks, edited by: Brooks, J., and Fleet, A. J., Special Publications, 26, Geological Society of London, Oxford, UK, 271-286, https://doi.org/10.1144/gsl.sp.1987.026.01.19, 1987. 